Trakya Eğitim Dergisi

Cilt 10, Sayı 1

Ocak 2020, 33-63

Geliş Tarihi:29.01.2019

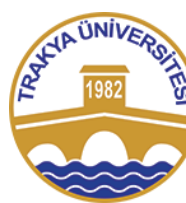

ISSN: 2630-6301

Doi: $10.24315 /$ tred.518969

Araştırma Makalesi/

Research Article
Trakya Journal of Education

Volume 10, Issue 1

January 2020, 33-63

Yayına Kabul Tarihi: 12.02 .2020

\title{
Öğretmen Adaylarının Medya Okuryazarlık Düzeyleri
}

\section{Media Literacy Level of Teacher Candidates ${ }^{1}$}

\section{Tugay TUTKUN ${ }^{2}$}

ÖZ: Medya araçlarının yaygınlaşması ve yoğun şekilde kullanılmas1 neticesinde "dijital toplum" olarak adlandırılabilecek geleneksel anlayıştan farklı olan bir toplum ve toplumsal katılım türü ortaya çıkmıştır. Facebook, Twitter, Instagram vb. sosyal ağlar bu tanımlamaya örnek olarak gösterilecek medya araçlarıdır. Araştırmanın temel amacı, öğretmen adaylarının genel olarak "değişik yapıdaki medya mesajlarına ulaşma, analiz etme, değerlendirme ve kullanabilme becerisi" olarak tanımlanabilecek olan medya okuryazarlık becerilerine ne derecede sahip olduklarının belirlenmesi ve bazı değişkenler açısından irdelenmesidir. Tarama modellerinden karşılaştırma türü ilişkisel tarama kullanılarak yapılan araştırmanın örneklemini 2011-2012 eğitim-öğretim yılında Çanakkale Onsekiz Mart Üniversitesi, Eğitim Fakültesinde 1. ve 4. sınıflarda öğrenim gören 1101 öğrenci oluşturmaktadır. Araştırmada kullanılan veri toplama aracı iki kısımdan; demografik özellikler ve Literat (2011) tarafindan geliştirilen ve çalışma kapsamında araştırmacı tarafından Türkçeye uyarlanan medya okuryazarlığı ölçeğinden oluşmaktadır. Sonuçlar öğretmen adaylarının, dijital medyayı kullanım sıklıkları, sosyal paylaşım ağlarında harcadıkları zaman ve medya okuryazarlık düzeyleri bakımında bazı farklılıklara sahip olduğunu göstermektedir.

Anahtar sözcükler: Medya, okuryazarlık, öğretmen adayı

\begin{abstract}
As a result of the widespread use of media tools, a society and social participation type different from the traditional approach which can be called "digital society" has emerged. Social networks such as Facebook, Twitter and etc. are examples of this media tools defined. The main purpose of the research is to determine the media literacy level of prospective teachers. Survey method is used in this casual comparative study. The sample of the research was consisted of 1101 students who were studying in Çanakkale Onsekiz Mart University, Faculty of Education in the academic year of 2011-2012. The data collection tool used in the research is composed of two parts; demographics and the media literacy scale which originally developed by Literat (2011) and adapted to Turkish by Tutkun (2013). The results show that preservice teachers' usage of digital media tools, time spent on social networks and media literacy levels have some differences according to class level, gender, personal computer internet connection.
\end{abstract}

Keywords: Media, literacy, teacher candidates

\section{Cite this article as:}

Tutkun, T. (2020). Media literacy level of teacher candidates. Trakya Eğitim Dergisi, 10(1), 33-63.

\section{EXTENDED ABSTRACT}

\section{Introduction}

There is no consensus on both definition and the name of the concept media literacy, since it is studied by different disciplines such as education, health, politics, religion, language etc. Terms such as; media education, media studies and media pedagogy are also used instead of media literacy in the literature. Federov (2008) bases the start of the media literacy movement on the movement of the cinema clubs, which emerged at the beginning of the 1920s. As the mass media rapidly emerged in number and scope and started to take an important place in daily life, the effects of media messages started to be discussed. Marshall McLuhan was the pioneer in this debate with his book "Understanding Media: The Extension of Man" which is published in 1964 (Hobbs and Jensen, 2009). In this debate, which grown in the following years especially concentrating on television, the idea of preparing individuals for this situation prevailed instead of blocking the media or rejecting its power, (Thoman, 1999). This situation is stated as "the school and family share the responsibility of preparing young people to live in a world full of powerful images, words and sounds" at the International Media Education Symposium organized

\footnotetext{
${ }^{1} \mathrm{Bu}$ çalışma, yazarın hazırladığı doktora tezinden üretilmiştir.

${ }^{2}$ Dr. Öğr. Üyesi, Çanakkale Onsekiz Mart Üniversitesi, Eğitim Bilimleri Bölümü, tugay@comu.edu.tr, ORCID: 0000-0003-0225-8614
} 
by UNESCO in Germany in 1982. In 1992, a group of academics interested in this emerging movement organized a conference in the US aiming to define a common conceptual framework of media literacy. In this conference, the concept of media literacy is defined as "the ability to access, analyze, evaluate and use media messages" (Aufderheide, 1993).

The importance of developing teachers' media literacy skills who have an impact on students' knowledge and learning is important. It is a social need to overcome the difficulties encountered in teachers' attitudes and qualifications in media literacy education, especially in teacher training curriculums and to include media literacy issues in the curriculums (Andersen, Duncan ve Pungente, 1999; Hobbs, 2010; Robertson ve Hughes, 2011). It is also accepted by the European Commission that media literacy is a key competence and should be included in teacher training programs (European Commission, 2011). In this context, the media literacy levels of teacher candidates are worthy of research. For this reason, it is aimed to examine the media literacy levels of teacher candidates in this study.

\section{Method}

Survey method is used in this casual comparative study. The sample of the research was consisted of 1101 students who were studying in Çanakkale Onsekiz Mart University, Faculty of Education in the academic year of 2011-2012. The data collection tool used in the research is composed of two parts; demographics and the media literacy scale which originally developed by Literat (2011) and adapted to Turkish by Tutkun (2013).

\section{Results and Discussion}

Results obtained related to frequency of usage in the research; (1) the frequency of using Internet and related media in prospective teachers differ by the grade level and (2) male students use internet resources more frequently than the female students, (3) the availability of access to the media also affects the frequency of media use are supported in the literature (Tsai, 2004; Martin, 2009; Literat, 2011; Tutkun, Demir and Genç, 2012; Silverblatt, 1995; Tsai, 2004; Buckingham, 2005; Jenkins, Clinton, Purushatma, Robison ve Weigel, 2007; UNESCO, 2008; Tornero ve Manuel, 2007; Almenara ve Liano, 2011; UNESCO, 2011).

Results obtained related to social network usage in the research; (1) candidate teachers spend more time on Facebook and Twitter than any other social networks, (2) female students are more interested in watching and sharing videos in social networks than male students, (3) male students spend more time in both offline and online video games than female students are similar to multiple studies in the field (Quaiser-Pohl, Geiser ve Lehmann, 2006; Hartmann ve Klimmt, 2006; Williams, Yee ve Caplan, 2008; Kim ve Kim, 2009; Williams, Consalvo, Caplan, ve Yee, 2009).

In general candidate teachers' level of media literacy is found to be not adequate in this research. Similar results obtained by multiple studies (Tiiede ve Grafe, 2016; Tornero ve Manuel, 2007; Torres, 2006; Robertson ve Hughes, 2011; Hunneshagen, 2005; Andersen, Duncan ve Pungente, 1999; Lauri, Borg, Günnel, ve Gillum, 2010).

Regarding the media literacy levels of teacher candidates, one of the findings obtained in this study is that the level of media literacy differs according to the departments. This finding is similar to the literature (Martin, 2009; Literat, 2011; Tutkun, Demir and Genç, 2012; Lenhart, 2009; Joinson, 2008; Caverlee and Webbs, 2008; Lewis, Kaufman, and Christakis, 2008; Martin, 2009); Lenhart, 2009). However, only two significant differences (Preschool Education-Science Education and Preschool Education-Computer and Instructional Technology) found between departments which is not fully supported by the literature.

It is noteworthy that many countries have recognized the importance of educating teachers about media literacy, and have begun to include relevant content teacher training programs (Hobbs, 2010; Torres, 2006; UNESCO, 2011; Almenara and Liano, 2011; Dezuanni, Kapitzke, and Iyer, 2010; UNESCO, 2008; Peterson and Knowles, 2009; Jenkins et al., 2007; Robertson and Hughes, 2011). The need to include media literacy knowledge and skills in teacher training programs is also valid for our country since media literacy related issues were not included until 2018 in our teacher training programs. As of this date, "Media Literacy" course in the teacher training programs is offered as a 
compulsory course in CIT department and as an elective course in other department's programs. In this context, initiatives to improve or support the media literacy levels of prospective teachers in our country are not sufficient. Prospective teachers should not be left to chance to develop their competencies in this regard, they should be handled more effectively in teacher training programs.

\section{GíRIŞ}

Medya okuryazarlığı eğitim, sağlık, siyaset, din, dil vb. farklı disiplinlerin çalışma alanı olduğundan gerek kavramın adı gerekse de tanımı konusunda bir uzlaşı yoktur. "medya okuryazarlığı" teriminin yerine "medya eğitimi (media education)", "medya çalışmaları (media studies)" ve "medya pedagojisi (media pedagogy)" gibi terimlerin de kullanıldığı da görülmektedir (Federov, 2008). Medya eğitimi daha çok Britanya'da ve Fransızca ile İspanyolca dillerinin konuşulduğu diğer ülkelerde kullanılagelen bir terimdir. Bu farkın sebebi İngilizce "okuryazarlık" (literacy) teriminin bu dillere çevrilmesinde yaşanan güçlüklerdir (Federov, 2008). Bunun yanında "medya eğitimi" daha çok süreci ifade ederken, "medya okuryazarlığı" ise bu sürecin sonucunda elde edilen ürünü ya da beceriyi ifade etmektedir. Ancak medya okuryazarlığı ve medya eğitimi birbiri yerine sıklıkla kullanılan aynı anlama sahip iki kavramdır (Kubey, 2001).

Federov (2008) medya okuryazarlığı kavramının ortaya çıkışını 1920'li yılların başlangıcında ortaya çıkan sinema kulübü hareketine dayandırmaktadır. Federov'a (2008) göre 1922 yılında Fransa'da yapılan Film Eğitimi Ulusal Konferansı'nda sinema eğitimcilerinin üniversite düzeyinde yetiştirilmesinin önerilmesi ve ardından 1936'da Fransa Eğitim Derneği'nin "sinema ve gençlik" adında çocukların filmler hakkında tartışma yaparak eleştirel düşünme, yaratıcılık ve artistik beğeni becerilerinin geliştirildiği faaliyetler medya okuryazarlığı hareketinin ilk örnekleridir. Medya eğitimi, İngiltere'de de diğer ülkelerde olduğu gibi benzer bir şekilde "film eğitimi" ile başlayarak diğer medya unsurlarını da zamanla içine almıştır. 1933 yılında İngiliz hükümeti tarafından kurulan "İngiliz Film Enstitüsü” bünyesindeki eğitim şubesi yıllarca öğretmenler için seminerler ve konferanslar vermiş, kitaplar ve öğretim materyalleri yayınlamıştır (Federov, 2008). Rusya'da ise basın ve film materyalleri hakkında eğitim süreci komünist ideolojinin ağırlıkla vurgulanmasıyla ortaya çıkmış ve 1960'lı yılların başlangıcından itibaren orta ve yükseköğretim düzeyinde ele alınmaya başlamıştır. 1950'li yıllarda İngiltere'de öğretmenler tarafından kurulan Film ve Televizyon Eğitim Topluluğu'nun "ekran eğitimi" kavramını ortaya atmasıyla çocukları sinema ve televizyonun ekranın etkilerinden korumak eğitimsel bir boyut kazanmıştır (Federov, 2008).

Kitle iletişim araçlarının sayı ve kapsam olarak hızla zenginleşip gelişmesi ve günlük hayatta önemli yer kaplamaya başlamasıyla bu araçlardan gelen mesajların etkileri tartışılmaya başlanmıştır. Bu tartışmanın öncü ismi 1964'te yayınladığı "Medyayı Anlamak: İnsanın Genişlemesi” adlı kitabıyla Marshall McLuhan olmuştur (Hobbs ve Jensen, 2009). İlerleyen y1llarda büyüyen ve özellikle televizyon üzerine yoğunlaşan tartışmada medyayı engellemek veya gücünü reddetmek yerine bireyleri bu duruma hazırlama düşüncesi hâkim olmuştur (Thoman, 1999). Bu durum UNESCO'nun 1982 yılında Almanya'da düzenlediği ve 19 ülkenin katıldığı Uluslararası Medya Eğitimi Sempozyumu sonucunda yayınlanan bildirgede "okul ve aile, gençleri etkili ve güçlü görüntüler, kelimeler ve seslerle dolu bir dünyada yaşamaya hazırlama sorumluluğunu paylaşmaktadır" şeklinde ifade edilmiştir (UNESCO, 1982). Ortaya çıkan medya okuryazarlığı hareketine ilgi duyan bir grup akademisyen 1992'de "medya okuryazarlığı" kavramının ortak bir kavramsal çerçeveye oturtulması amaciyla ABD'de Medya Okuryazarlığı Ulusal Liderlik Konferansı'nı düzenlemiştir. Bu konferansta medya okuryazarlığı kavramı "değişik yapıdaki medya mesajlarına ulaşma, analiz etme, değerlendirme ve kullanabilme becerisi" olarak tanımlanmıştır (Aufderheide, 1993).

Silverblatt (1995) medya okuryazarlığını "bireyin medya içeriği üzerinde yorum ve algı yetisinin artması" olarak tanımlamıştır. Buckingham (2003) ise medya okuryazarlığını "medyanın kullanılışı ve yorumlanışı sırasında gerekli olan bilgi, beceri ve yeterlilikler" olarak tanımlamıştır. Schwarz da (2005) medya okuryazarlığını, "medya mesajlarını anlamlandırmak, yorumlamak ve yenilerini üretmekle ilgili bir kavram" olarak tanımlayarak, yeni medya mesajları oluşturmayı da tanıma eklemiştir. Benzer bir tanımla Livingstone ve Wang (2011) da medya okuryazarlığının, medyanın anlaşılmasının yanında, onun bir bilgi edinme, eğlence, zenginleşme, gelişme, yetkilendirme ve iletişim kaynağı olarak kullanılmasına işaret ettiğini vurgulamaktadır. Federov (2008) medya okuryazarlığını "medya 
materyallerini kullanarak medya ile ilgili kişilik gelişiminin sağlanması" şeklinde tanımlamıştır. Radyo ve Televizyon Üst Kurulu (2008) ise medya okuryazarlığını "yazılı ve yazılı olmayan, büyük çeşitlilik gösteren formatlardaki (televizyon, video, sinema, reklâmlar, internet vs.) mesajlara ulaşma, bunlar çözümleme, değerlendirme ve iletme yeteneği kazanabilmek" olarak tanımlamaktadır. Tanımları çoğaltmak mümkün olsa da tanımlamalarda genelde iki temel unsur dikkat çekmektedir. Bunlardan ilki, bireyin medya tarafından kendisine ulaştırılan mesajları süzme, değerlendirme ve doğru şekilde anlamlandırma becerisi, ikincisi ise kişinin medya mesajları üretebilmesi ve oluşturabilmesi için gerekli bilgi ve becerilerdir. Medya okuryazarlığı kavramını tanımlama konusunda eğitim, iletişim medya vb. farklı alanlardaki uzmanların farklı yaklaşımlar bulunmaktadır (Potter, 2005). Kavramın tanımı konusunda tam bir birliktelik olmasa da bütün yaklaşımların ve uzman gruplarının genel olarak kabul ettiği bazı anahtar kavram ve ilkeleri şu şekilde listelemek mümkündür (Thoman ve Jolls, 2003):

- Tüm medya mesajları yapılandırılmış, kurgulanmıştır.

- Medya mesajları kendi kuralları olan yaratıcı bir dil kullanılarak oluşturulur.

- Bireyler aynı medya mesajını farklı algılarlar.

- Medyanın mesajlarının içinde değerler ve bakış açıları vardır.

- Birçok medya mesajı kazanç veya güç elde etmek için oluşturulmuştur.

Namita'ya (2010) göre medya okuryazarlı̆̆ tarihsel gelişim süreci içerisinde dört ana; korumacı, sanatsal, ideolojik ve hazırlamacı yaklaşıma, sahiptir. Korumacı (aşılayıcı) yaklaşım; bireylerin medyaya karşı pasif olduğunu ve medyanın bireylerin yaşamlarını etkilediğini ifade etmektedir. $\mathrm{Bu}$ bağlamda, medya okuryazarlığı eğitimi ile bireylerin ve toplumun medyanın ortaya çıkardığ 1 kültürel yozlaşma, sanat ve edebiyattaki bozulma gibi olumsuz etkilerden korunması hedeflenmektedir. Sanatsal yaklaşım; medyanın kültürel ve sanatsal değerler üreterek topluma katkı sağladığı temeline dayanmaktadır. Buckingham'a (2009) göre sanatsal yaklaşımda medya, kültürel varlıkları korumak ve yeni nesillere aktarmak fonksiyonuyla topluma katkıda bulunmaktadır. İdeolojik yaklaşım; medyanın gerçeği tarafsız bir şekilde sunmadığı, aksine kurgulanarak kendi amacına uygun hale getirilerek sunulduğu temeline dayanmaktadır. Bu yaklaşıma göre medya bize dünyayı nasıl algılamamız gerektiği hususunda dayatmalar yapmaktadır. Bu sebeple Masterman'a (2001) göre medya okuryazarlığ eğitiminin amacı, öğrencilere medya iletilerini değerlendirebilme becerisi kazandırmak olmalıdır. Hazırlamacı yaklaşım; korumacı ve ideolojik yaklaşımın aksine bireyi pasif ve medya iletilerine maruz kalan bir unsur olarak değil, aynı zamanda medya iletilerini yorumlayan ve tekrardan oluşturan ve ileten aktif bir unsur olarak ele almaktadır. Bu yaklaşımla birlikte medya okuryazarlığı anlayışı bireylerin pasif alıc1 ya da kurban olarak korunması gerekliliğinden, aktif ve üretici olarak yetiştirilmesine dönüşmüştür (Buckingham, 2009). Richardson (2009) da medya okuryazarlığı eğitimine yönelik yaklaşımları iki temel gruba ayırmaktadır. Bunlardan ilki; temelde medyanın olumsuz etkilerinin engellenmesine yönelik uygulamalara dayanan, bireylere eleştirici ve kültürlü tüketiciler olma yolunda yardım etmeyi amaçlayan korumacı (önleyici, aşılayıcı ya da müdahaleci) yaklaşımdır. İkincisi ise temelde vatandaşlık uygulamalarına ve eleştirel ve kültürel çalışmalara dayanan ve bireyleri eleştirici ve kültürlü tüketiciler haline getirmenin ötesinde aktif, eleştirel ve kültürlü vatandaşlar haline getirmeyi amaçlayan yaklaşımlardır (Silva ve Wyatt, 2007; Richardson, 2009).

\subsection{Medya Okuryazarlığının Yapısı ve Kapsamı}

Aufderheide'nin (1993) tanımından; "değişik yapıdaki medya mesajlarına ulaşma, analiz etme, değerlendirme ve kullanabilme becerisi" hareketle medya okuryazarlığının kapsadığı dört temel beceriyi; erişim, analiz, değerlendirme ve üretim (sentez) olarak ifade etmek mümkündür. $\mathrm{Bu} 4$ becerinin Bloom taksonomisindeki bilişsel alan davranış aşamaları ile benzerliği dikkat çekici olsa da medya okuryazarlı̆̆ 1 sadece bilişsel alanda edinilen öğrenme ürünlerinden oluşmamaktadır; bilişsel boyutunun yanında duyuşsal, ahlaki ve estetik boyutları da vardır (Potter, 2005). UNESCO (2008) medya okuryazarlığı eğitiminin bireylere kazandırmayı hedeflediği 5 temel beceriyi (1) kaynaklara erişim ve seçim, (2) eleştirel okuma, (3) üretim ve ifade etme (4) kendine mal etme ve (5) katılım olarak listelemiştir. 
Geleneksel olarak, radyo, televizyon, basılı medya kaynaklarını kapsayan medya okuryazarlığının içeriği de bilgi ve iletişim teknolojilerinin hızla gelişmesi, internetin ortaya çıkışı ve yaygınlaşması, sosyal ağların yaygınlaşması vb. neticesinde değişim göstermiş ve sonucunda yeni medya okuryazarlık türleri ortaya çıkmıştır. Bu yeni medya okuryazarlık kavramı işbirliği ve ağ paylaşımı ile şekillenen sosyal becerileri kapsamaktadır. Bu beceriler geleneksel okuryazarlığın; araştırma, teknik ve eleştirel düşünme becerileri üzerine inşa edilmektedir. Bu bağlamda yeni medya okuryazarlıkları bireylerin kendilerini ifade etme becerileriyle sınırlandırılmamalı, toplumla etkileşimi sağlayan sosyal beceriler olarak ele alınmalıdır (Jenkins ve ark., 2006). Medya okuryazarlığını sosyal bir beceri olarak ele alan Jenkins ve ark. (2006), günümüz medya çevrelerine katılabilmek için gerekli olan, medya okuryazarlığının kapsadığı 12 beceriyi şu şekilde tanımlamaktadır;

- Oynama-Deneme: Problem çözmeye yönelik olarak çevresiyle deneysel bir biçimde etkileşebilme kapasitesini ifade etmektedir.

- Yapma-İcra Etme: Doğaçlama ya da keşfetmek amaçli çeşitli kimlikleri uyarlayabilme, benimseyebilme becerisidir.

- Simülasyon-Benzetim: Gerçek yaşamda karşılaşılan durumları açıklama, yorumlama ve zihinde dinamik modellerini oluşturma becerisidir.

- Uyarlama-Kendine Mal Etme: Medya içeriğini yeniden ve anlamlı bir biçimde kendince örneklendirme ve sentezleme becerilerini, medya içeriğini önce ayrıştırarak daha sonra farklı ve özgün bir biçimde yeniden oluşturmayı içermektedir.

- Çoklu Görev: Çevreyi tarama, inceleme ve odak noktasını göze batan dikkat çekici detaylara yönlendirme becerilerini ifade etmektedir.

- Yayılmış-Genişletilmiş Biliş: Zihinsel kapasitesini genişletmeye yönelik olarak medya araçlarını kullanabilme becerisini ifade etmektedir.

- Ortak Akıl: Ortak bir amaç için bilgi toplama ve elde ettiklerini diğerleriyle paylaşma becerisini ifade etmektedir.

- Muhakeme: Farklı bilgi kaynaklarının güvenirliğini ve inanılırlığını değerlendirme becerilerini ifade etmektedir.

- Ortamlar Arası Konumlandırma: Medyada sunulan bilgi ve hikâyeleri farklı medya ortamlarında; televizyon, internet, radyo vb. takip etme becerisini ifade etmektedir.

- Ağ Paylaşımı: Sentezleme ve yayma amaçlı bilgi araştırma ve paylaşma becerisini ifade etmektedir.

- Müzakere: Farklı topluluklar arasında yol alma, farklı bakış açılarına saygı duyma ve anlayışlı olma ve alternatif yapıları fark etme ve izleme becerisini ifade etmektedir.

- Görselleştirme: Bilginin görsel olarak ortaya çıkartılması ve anlamlandırılmasını ifade etmektedir.

\subsection{Medya Okuryazarlığı ve Eğitim Programları}

Buckingham'a (2005) göre medya okuryazarlığı üç temel amaca; (1) demokrasi, katılım ve aktif vatandaşl1k, (2) bilgi ekonomisi, rekabetçilik ve seçim, (3) hayat boyu öğrenme, kültürel iletişim, kişisel tatmin hizmet etmektedir. Thoman ve Jolls (2003); beş sebeple; (1) medyanın demokrasi sürecindeki etkisi, (2) medyanın yüksek oranda kullanılması ve toplumun medya ile doyurulması, (3) medyanın algıları, inançları ve tutumları şekillendirmekteki etkisi, (4) görsel iletişim ve bilginin artan önemi, (5) bilgi toplumunun ve hayat boyu öğrenmenin önemi, medya okuryazarlığının önemli olduğunu belirtmektedir. Hobbs ve Jensen (2009) medya okuryazarlığının dijital medyanın yükselmesiyle; (1) kişisel ve sosyal kimlikle ilgili sorunlar, (2) özel ve kamusal olma ile ilgili sorunlar ve (3) yasal ve etik ile ilgili sorunların çözümü için önem arz ettiğini ifade etmektedir. Jenkins (2006) ise medya okuryazarlığı eğitiminin eğitim sürecinde yer almasına 3 nedenden; (1) katılım farklılıkları, (2) şeffaflık problemi ve (3) etik sorunlar, dolayı ihtiyaç duyulduğunu belirtmektedir.

Medya okuryazarlığı becerilerine eğitim programlarında yer verilmesini hususunda iki farklı yaklaşım; (1) özerk bir ders olarak ya da (2) mevcut derslerle ilişkilendirerek, ön plana çıkmaktadır 
(Duncan, 1989; Hobbs, 1998; 2010; Scharrer, 2003). Özerk bir ders olarak eğitim programlarında yer verilmesi, medya okuryazarlığı konu ve becerilerinin tek bir ders altında toplanması ve bu şekilde okutulmasını öngörmektedir. İlişkilendirme yaklaşımında ise ilgili becerilerin özerk ders olarak okutulması durumunda hedeflere tam ulaşılamayacağı kaygısıyla (Hobbs, 1998) ilgili becerilere programlarda yer alan diğer dersler içerisinde ele alınması görüşü ön plana çıkmaktadır.

Birçok ülke kendine göre bir medya okuryazarlığı anlayışı geliştirerek kendi eğitim sistemlerine az ya da çok dâhil etmiştir. Ancak ülkeler üstü statüye sahip olan; UNESCO, UNICEF, Avrupa Birliği, OECD gibi bazı kuruluşlar da medya okuryazarlığı eğitimi konusunda çalışmalar; konferans, panel vb. toplantılar, çerçeve planlar, öğretim programları vb. materyaller hazırlayıp ülkeleri ve bireyleri teşvik etmeye ve yönlendirmeye çalışmaktadırlar. 1980'lerden itibaren Amerika Birleşik Devletleri'nin bazı eyaletlerinde çocuk ve gençleri medyanın etkilerinden koruyup daha bilinçli bireyler olmalarına yardımcı olmak için medya okuryazarlığı konuları eğitim programlarına dâhil edilmiştir. Benzer şekilde günümüzde Fransa, İngiltere, Almanya, ABD, Kanada, Avustralya, Yeni Zelenda, Japonya, Çin, Türkiye gibi birçok ülkede medya okuryazarlığı ile ilgili içerikler eğitim programlarında yer bulmaktadır. Ülkemizde de Radyo ve Televizyon Üst Kurulu (RTÜK) ve Milli Eğitim Bakanlığı'nın (MEB) işbirliğiyle gerçekleştirilen "Medya Okuryazarlığı Projesi" neticesinde Medya Okuryazarlığ dersi 2007-2008 eğitim-öğretim yılından itibaren seçimlik bir ders olarak ilköğretim 6-8. sınıflarda okutulmaya başlanmıştır.

\subsection{Medya Okuryazarlığı ve Öğretmen Yetiştirme}

Medya okuryazarlı̆̆ eğitimi genel olarak ilköğretim düzeyinde ele alınsa da temel bir vatandaşlık yeterliği olduğu dikkate alındığında sadece çocuklar ve temel eğitim ile sınırlı olmadığı, aynı zamanda yetişkinler, ebeveynler, öğretmenler ve medya çalışanları için de temel bir beceri olduğu son derece açıktır (Thoman ve Jolls, 2004). UNESCO (2011) medya okuryazarlığının formal eğitim programlarında yer almasının yanında özellikle yetişkin eğitimi ve hayat boyu eğitim bağlamında da ele alınması gerekliliğini vurgulamaktadır. Ülkemizde medya okuryazarlığı becerileri 2007 yılından itibaren ilköğretim düzeyinde seçmeli "medya okuryazarlığı" dersi ile geliştirilmeye çalışılmış olsa da yükseköğretim düzeyinde 2018 yılına kadar genel olarak ele alınmamıştır. Bu tarihten itibaren uygulamaya koyulan öğretmen yetiştirme programlarında ise "Medya Okuryazarlığı" dersi BÖTE bölümü programında alan eğitimi bünyesinde zorunlu bir ders diğer programlarda ise seçmeli ders kategorisinde okutulmaya başlanmıştır. Bunun yanı sıra medya okuryazarlığ 1 becerilerinin yetişkin eğitimi bünyesinde ele alındığını söylemek de mümkün değildir.

Öğretmen yetiştirme sürecinde medya okuryazarlığ farklı ülkelerde formal ve informal eğitim kapsamında ele alınmaktadır. İngiltere, Avustralya, İtalya Kanada ve ABD'de öğretmenler için formal olarak çalıştaylar, seminerler yaz okulları vb. düzenlenirken bazı ülkelerde öğretmenler medya okuryazarlığ konusunda sivil toplum kuruluşları, medya aktörleri ve medya çalışanları ve tarafından desteklenmektedir. Hobbs'a (2007) göre öğretmen yetiştirme sürecinde medya okuryazarlığ becerilerinin öğretmenlere kazandırılması hususunda (1) kendi kendine öğrenme, (2) hizmet-içi eğitim, eğitim programı temelli yaklaşım, (3) uzmanlarla işbirliği, yükseköğretim düzeyinde ders verme gibi yaklaşımlar uygulanmaktadır.

Medya okuryazarlığı eğitiminde öğretmenlerin tutum ve niteliklerinden dolayı karşılaşılan güçlükleri yenmekte özellikle öğretmen yetiştirme programlarına büyük görevler düşmekte ve programlarda medya okuryazarlığı konularına yer verilmesi gerekliliği toplumsal bir ihtiyaç olarak karşımıza çıkmaktadır (Andersen, Duncan ve Pungente, 1999; Hobbs, 2010; Robertson ve Hughes, 2011). Medya okuryazarlığının anahtar bir yeterlik olduğu ve öğretmen yetiştirme programlarında yer verilmesinin gerekli olduğu Avrupa Komisyonu tarafindan da kabul gören bir düşüncedir (European Commission, 2011). Hobbs (2010) medya okuryazarlı̆̆ eğitimini öğretmen yetiştirme sistemlerinde ele almasına ve medya ile işbirliğinin geliştirilmesine yönelik olarak şu tavsiyelerde bulunmuştur:

- Medya okuryazarlığ eğitiminin temel prensiplerinin öğretmen yetiştirme programlarına entegre edilebilmesi için yükseköğretim düzeyinde disiplinler arası bir köprü kurulmasının desteklenmesini

- Toplum ve medya ortaklığıyla öğretmenlerin dijital ve medya okuryazarlığı bağlamında desteklenmesi için öğretim kademeleri temelinde girişimlerin desteklenmesini 
- Toplumsal katılımı teşvik edecek biçimde yerel ve ulusal haber medyalarını eğitim programlarıyla daha fazla ilişkilendirmek için medya ve teknoloji şirketleriyle işbirliği yapilmasinı

- Medya okuryazarlığı uzmanlığının geliştirilmesinde öğretmeler için çevrimiçi kaynakların hazırlanmasinı tavsiye etmektedir.

\subsection{Araștırmanın Amacı}

Gerek formal gerekse informal eğitim vasıtasıyla öğrencilerin bilgi ve becerileri üzerinde etkisi olan öğretmenlerin, medya okuryazarllğı becerilerin geliştirilmesi alanyazına ve yurtdışındaki uygulamalara bakıldığında önem arz emektedir. Medya okuryazarlığ ile ilgili beceriler MEB tarafindan belirlenen "öğretmenlik mesleği genel yeterlikleri" kapsamında doğrudan ve dolaylı olarak yer almaktadır. Bu bağlamda, öğretmen adaylarının medya okuryazarlık düzeyleri araştırmaya değer bir konudur. Bu nedenle, yapılan bu araştırmada, öğretmen adaylarının medya okuryazarlık düzeyinin bazı değişkenler açısından incelenmesi amaçlanmıştır. Bu bağlamda araştırmada cevabı aranan sorular şu şekildedir:

1) Öğretmen adaylarının dijital medya araçlarını haftalık kullanım süresi ne düzeydedir?

2) Öğretmen adaylarının dijital medya araçlarını haftalık kullanım süresi; öğrenim gördükleri sınıf düzeyine, cinsiyete, kişisel bilgisayara sahip olma durumuna, internet bağlantısına sahip olma durumuna ve öğrenim gördükleri anabilim dalına göre farklılık göstermekte midir?

3) Öğretmen adaylarının sosyal ağları haftalık kullanım süresi ne düzeydedir?

4) Öğretmen adaylarının sosyal ağlar haftalık kullanım süresi; öğrenim gördükleri sınıf düzeyine, cinsiyete, kişisel bilgisayara sahip olma durumuna, internet bağlantısına sahip olma durumuna ve öğrenim gördükleri anabilim dalına göre farklılık göstermekte midir?

5) Öğretmen adaylarının medya okuryazarlık düzeyleri ne seviyededir?

6) Öğretmen adaylarının medya okuryazarlık düzeyleri; öğrenim gördükleri sınıf düzeyine, cinsiyete, kişisel bilgisayara sahip olma durumuna, internet bağlantısına sahip olma durumuna ve öğrenim gördükleri anabilim dalına göre farklılık göstermekte midir?

7) Medya okuryazrlık düzeyinin yordayıcı değişkenleri nelerdir?

\section{YÖNTEM}

Karşılaştırma türü ilişkisel tarama niteliğinde olan bu araştırmada öğretmen adaylarının dijital medya araçlarını kullanma düzeyleri, sosyal medyayı kullanma düzeyleri ve medya okuryazarlık düzeylerinin belirlenmesi ve bazı değişkenler (öğrenim gördükleri sınıf düzeyi, cinsiyet, kişisel bilgisayara ve internet bağlantısına sahip olma durumu ve öğrenim görülen anabilim dalı) açısından irdelenmesi amaçlanmıştır. Karşılaştırma türü ilişkisel tarama modellerinde, en az iki değişken bulunup bunlardan birine göre gruplar oluşturularak diğer değişkene göre aralarında bir farklılaşma olup olmadığ 1 incelenir (Karasar, 2005).

\subsection{Evren ve Örneklem}

Araştırmanın evrenini 2011-2012 Eğitim-Öğretim yılında Çanakkale Onsekiz Mart Üniversitesi, Eğitim Fakültesi'nde öğrenim görmekte olan öğretmen adayları oluşturmaktadır. Araştırmanın örneklemi tabakalı örnekleme yoluyla belirlenmiştir. Tabakalı örneklem alma yöntemi, sosyal bilimlerde sıklıkla kullanılan ve özellikle homojen olmayan evrenlerde uygundur (Baykul, 1999). Tabakalı örnekleme tekniği, örneklemin standart hatasını azaltmasının yanında, araştırmanın daha ekonomik koşullarda ve kısa zamanda yapılmasını sağlar (Miles ve Huberman, 1994). Araştırmanın amacı bakımından evrendeki her bir tabakanın yüzdeliğine göre örnekleme yansımasının önemli olup olmayışına göre tabakalardan örnek seçme işlemi oranlı ya da oransız olmak üzere iki şekilde yapılabilir (Baykul, 1999; Balc1, 2004). Tabakalı örneklemenin temsili bir örneklem oluşturabilmesi için çok sayıda kümenin seçilmesi gerekir (Karasar, 2005). Bu bağlamda, araştırmanın örneklemi oransız 
tabakalı örnekleme yoluyla tespit edilmiştir. Araştırmada ÇOMÜ, Eğitim Fakültesi'ne bağlı ve öğrencisi bulunan 12 anabilim dalı; Alman Dili Eğitimi, Bilgisayar ve Öğretim Teknolojileri Eğitimi, Coğrafya Eğitimi, Fen Bilgisi Eğitimi, İngiliz Dili Eğitimi, Japon Dili Eğitimi, Müzik Eğitimi, Okul Öncesi Eğitimi, Resim-İ̉ Eğitimi, Sınıf Öğretmenliği, Tarih Eğitimi ve Türkçe Eğitimi tabaka olarak ele alınmıştır. Bu anabilim dallarında öğrenim gören öğrencilerden sadece 1. ve 4. sınıfta öğrenim görmekte olan adaylar; aldıkları eğitimin araştırmada ele alınan medya okuryazarlık becerilerini ne şekilde etkilediğini belirleyebilmek amaciyla örnekleme dâhil edilmiştir.

Tablo 1. Katılımcıların sınıf, cinsiyet ve anabilim dalına göre dağılımı

\begin{tabular}{|c|c|c|c|c|c|c|}
\hline \multirow{2}{*}{ Anabilim Dalı } & \multirow{2}{*}{ Cinsiyet } & \multicolumn{2}{|c|}{ Sinıf } & \multirow{2}{*}{$\begin{array}{l}\text { Cinsiyet } \\
\text { Toplam }\end{array}$} & \multirow{2}{*}{$\begin{array}{c}\text { Bölüm } \\
\text { Toplam } \\
\end{array}$} & \multirow{2}{*}{$\begin{array}{l}\text { Bölüm } \\
\text { Yüzde }\end{array}$} \\
\hline & & 1. Sinif & 4. Sinıf & & & \\
\hline \multirow[t]{2}{*}{ Alman Dili Eğitimi } & K & 35 & 22 & 57 & \multirow{2}{*}{62} & \multirow{2}{*}{5.6} \\
\hline & $\mathrm{E}$ & 2 & 3 & 5 & & \\
\hline \multirow[t]{2}{*}{ BÖTE } & K & 33 & 19 & 52 & \multirow{2}{*}{116} & \multirow{2}{*}{10.5} \\
\hline & $\mathrm{E}$ & 27 & 37 & 64 & & \\
\hline \multirow[t]{2}{*}{ Coğrafya Eğitimi } & K & 4 & 10 & 14 & \multirow{2}{*}{53} & \multirow{2}{*}{4.8} \\
\hline & $\mathrm{E}$ & 23 & 16 & 39 & & \\
\hline \multirow[t]{2}{*}{ Fen Bilgisi Eğitimi } & K & 57 & 45 & 102 & \multirow{2}{*}{135} & \multirow{2}{*}{12.3} \\
\hline & E & 10 & 23 & 33 & & \\
\hline \multirow[t]{2}{*}{ İngiliz Dili Eğitimi } & K & 32 & 50 & 82 & \multirow{2}{*}{109} & \multirow{2}{*}{9.9} \\
\hline & $\mathrm{E}$ & 20 & 7 & 27 & & \\
\hline \multirow[t]{2}{*}{ Japon Dili Eğitimi } & K & 14 & 15 & 29 & \multirow{2}{*}{43} & \multirow{2}{*}{3.9} \\
\hline & $\mathrm{E}$ & 8 & 6 & 14 & & \\
\hline \multirow[t]{2}{*}{ Müzik Eğitimi } & K & 17 & 17 & 34 & \multirow{2}{*}{51} & \multirow{2}{*}{4.6} \\
\hline & $\mathrm{E}$ & 9 & 8 & 17 & & \\
\hline \multirow[t]{2}{*}{ Okul Öncesi Eğitimi } & K & 69 & 68 & 137 & \multirow{2}{*}{152} & \multirow{2}{*}{13.8} \\
\hline & $\mathrm{E}$ & 13 & 2 & 15 & & \\
\hline \multirow[t]{2}{*}{ Resim-İş Eğitimi } & K & 24 & 19 & 43 & \multirow{2}{*}{50} & 15 \\
\hline & $\mathrm{E}$ & 3 & 4 & 7 & & 4.5 \\
\hline Sınıf Ö̆gretmenliği & K & 58 & 56 & 114 & 163 & 18 \\
\hline & $\mathrm{E}$ & 16 & 33 & 49 & & \\
\hline Tarih Eğitimi & K & 5 & 15 & 20 & 40 & \\
\hline & $\mathrm{E}$ & 19 & 10 & 29 & 49 & 4.5 \\
\hline Türkçe Eğitimi & K & 37 & 30 & 67 & 118 & 107 \\
\hline & $\mathrm{E}$ & 20 & 31 & 51 & 118 & 10.1 \\
\hline Toplam & & $555(\% 50.4)$ & $546(\% 49.6)$ & & 1101 & \\
\hline
\end{tabular}

Tablo 1 araştırmaya katılan öğretmen adaylarının anabilim dalı, cinsiyet ve sınıfına göre dağglımını göstermektedir. Buna göre öğretmen adaylarının 555'i (\% 50.4) 1.sınıf, 546's1 (\% 49.6) ise 4. sınıfta öğrenim görmektedir. Araştırmaya katılan öğretmen adaylarının \% 5.6'sı Alman Dili Eğitimi, \% 10.5'i BÖTE, \% 4.8'i Coğrafya Eğitimi, \% 12.3'ü Fen Bilgisi Eğitimi, \% 9.9'u İngiliz Dili Eğitimi, \% 3.9'u Japon Dili Eğitimi, \% 4.6's1 Müzik Eğitimi, \% 3.8'i Okul Öncesi Eğitimi, \% 4.5'i Resim-İşs Eğitimi, \% 14.8'i Sınıf Öğretmenliği, \% 4.5'i Tarih Öğretmenliği ve \% 10.7'si ise Türkçe Eğitimi anabilim dalında öğrenim görmektedir. 


\subsection{Veri Toplama Araçları}

Araştırmada kullanılan veri toplama aracı iki ana bölümden oluşmaktadır. Birinci bölümde öğretmen adaylarının öğrenim gördükleri sınıf düzeyi, cinsiyet, öğrenim gördükleri bölüm/anabilim dalı, bilgisayara ve internet bağlantısına sahip olma durumunu belirlemeyi amaçlayan 5 madde bulunmaktadır. İkinci bölüm ise Literat (2011) tarafından geliştirilen ve Tutkun (2013) tarafından Türkçeye uyarlanan medya okuryazarlığı ölçeğinden oluşmaktadır. Medya okuryazarlığı ölçeği de kendi içerisinde üç kısımdan oluşmaktadır. Birinci kısımda katılımcıların dijital medya araçlarının beş farklı kullanım biçiminde haftalık olarak harcadıkları süreyi ölçmeyi amaçlayan beş madde, ikinci kısımda katılımcıların dokuz farklı sosyal medya ortamında haftalık olarak harcadıkları süreyi ölçmeyi amaçlayan dokuz madde bulunmaktadır. İlk iki kısımdaki 14 madde 1-5 arasında ( $1=$ Hiç, 2=1-10 saat, $3=11-20$ saat, $4=21-30$ saat ve $5=30$ saat ve üzeri) puanlanacak şekilde hazırlanmıştır. Medya okuryazarlığı ölçeğinin asıl gövdesini oluşturan üçüncü bölümde ise 12 medya okuryazarlı̆̆ 1 becerisini ölçmeyi amaçlayan toplam 43 madde yer almaktadır. Bu maddeler Likert tipi 5'li dereceleme ölçeği ile 1-5 arasında (1=Kesinlikle Katılmiyorum, 2=Katılmiyorum, 3=Kararsizım, 4=Kat1liyorum, 5=Kesinlikle Katılıyorum) puanlanacak şekilde düzenlenmiştir. Ölçeğin tamamı ve alt boyutları için iç tutarlı̆̆ını belirlemek amaciyla Cronbach's Alpha katsayısı hesap edilmiştir. Sonuç olarak ölçeğin tamamının güvenirliği 0.901 , ölçeğin alt boyutlarındaki güvenirlik katsayılarının ise 0.600 ile 0.818 arasında değişiklik gösterdiği belirlenmiştir.

\subsection{Verilerin Analizi}

Verilerin analizi aşamasında ilk olarak verilerin SPSS 18.0 paket programına aktarılması yapılmıştır. Analiz sürecine devam etmeden önce veriler gözden geçirilmiş, maddelere ait kayıp değerler kişi bazında madde sayısının \% 5'ini geçmemesi kaydıyla (Field, 2005) o maddelere ait serinin ortalaması ile değiştirilmiştir. Kayıp değerlerin \% 5'i geçtiği durumlarda ise o kişilere ait veriler analiz sürecinden çıkarılmıştır. Verilerin analizinde kullanılacak dağılımların normalliğini kontrol etmek amacıyla her bir dağılımın çarpıklık ve basıklık katsayıları hesaplanarak kendi standart hatalarına bölünmüştür. Elde edilen sonuçlar tüm dağılımlarda, dağılımın normal kabul edilmesi için yeterli bir ölçüt olarak kabul edilen -2 ile +2 arasında olduğunu (Field, 2005) göstermiş, böylelikle bütün analiz işlemlerinde parametrik testlerin kullanılabileceğine karar verilmiştir.

\section{BULGULAR}

Bu bölümde araştırmada elde edilen bulgular tablolar halinde sunularak yapılan analiz sonuçları ile birlikte açılanmaktadır.

Tablo 2. Öğretmen adaylarının dijital medya araçlarını haftalık kullanma süresi ortalamaları

\begin{tabular}{lccc}
\hline Medya Kullanımı & f & $\overline{\mathbf{x}}$ & Ss \\
\hline İnternette okul ile ilgili işler için & 1101 & 2.15 & 0.943 \\
İnternette boş zamanlarınızı değerlendirmek için & 1101 & 2.47 & 0.735 \\
TV seyretmek (internet üzerinden olmayan) için & 1093 & 1.84 & 0.609 \\
Kitap, dergi ve gazete okumak için & 1093 & 2.22 & 0.807 \\
İnternet, cep telefonu, PlayStation vb. üzerinden oyun oynamak için & 1098 & 1.84 & 0.930 \\
\hline
\end{tabular}

Tablo 2, dijital medya araçlarının kullanım biçim ve sıklığını göstermektedir Buna göre öğretmen adaylarının dijital medya araçlarını en çok "internette boş zamanlarınızı değerlendirmek" amacıyla kullandığ en az ise, "internet, cep telefonu, Play Station vb. üzerinden oyun oynamak" amaciyla kullandığ 1 göze çarpmaktadır. Öğretmen adaylarının dijital medya araçlarını "internette okul ile ilgili işler" ve "kitap, dergi, gazete vb. okumak" amacıyla kullanım düzeylerinin boş zamanlarını değerlendirme amacıyla kullanım düzeyinden daha düşük olması dikkat çekmektedir. Bu durum öğretmen adaylarının dijital medya araçlarını daha çok zaman geçirmek ya da eğlence amaçlı kullandığı şeklinde yorumlanabilir. Verileri toplamak için kullanılan aracın 1-5 arasında (1=Hiç, 2=1-10 saat, $3=11-20$ saat, $4=21-30$ saat ve $5=30$ saat ve üzeri) ölçme yaptığı dikkate alındığında öğretmen adayları 
haftalık olarak; internette boş zaman değerlendirmek, kitap, dergi ve gazete okumak, internette okul ile ilgili işler, TV seyretmek ve internet ile cep telefonu, Play Station vb. üzerinden oyun oynamak kategorilerinden her biri için ortalama 1 ile 10 saat arasında zaman harcamaktadır.

Tablo 3. Öğretmen adaylarının dijital medya araçlarından interneti boş zamanlarını değerlendirmek için kullanma süresinin sınıf, cinsiyet, kişisel bilgisayara sahip olma durumu ve internet bağlantısına sahip olma durumuna göre karşılaştırılması

\begin{tabular}{llcccccc}
\hline & & f & $\overline{\mathbf{x}}$ & Ss. & $\mathbf{t}$ & Sd. & p \\
\hline Sinıf & 1 & 555 & 2.48 & .951 & \multirow{2}{*}{.0505} & \multirow{2}{*}{1099} & .614 \\
Cinsiyet & 4 & 546 & 2.45 & .936 & & & \\
& Kadın & 751 & 2.39 & .892 & -3.840 & 1099 & $.000^{*}$ \\
PC Sahibi Olma & Erkek & 350 & 2.63 & 1.027 & & & \\
& Evet & 927 & 2.52 & .936 & \multirow{2}{*}{.079} & 1099 & $.000^{*}$ \\
İnternet Bağlantısına & Hayır & 174 & 2.20 & .937 & & & \\
Sahip Olma & Evet & 897 & 2.56 & .943 & \multirow{2}{*}{6.820} & 1099 & $.000^{*}$ \\
\hline Hayır & 204 & 2.07 & .834 & & &
\end{tabular}

Tablo 3'e göre öğretmen adaylarının dijital medya araçlarından interneti boş zamanlarını değerlendirmek için haftalık kullanma sürelerinin sınıf, cinsiyet, kişisel bilgisayara ve internet bağlantısına sahip olma durumuna göre karşılaştırılma sonuçlarını göstermektedir. Buna göre;

- 1. Sınıfta öğrenim gören adaylarının ortalamaları $(\overline{\mathrm{x}}=2.48$; Ss. $=0.95)$ ile 4. Sınıfta öğrenim gören adayların ortalamaları $(\overline{\mathrm{x}}=2.45$; Ss. $=0.94)$ arasında istatistiksel olarak anlamlı bir fark olmadığ tespit edilmiştir $\left(\mathrm{t}_{1099}=0.0505 ; \mathrm{p}>0.05\right)$.

- Kadın adaylarının ortalamaları $(\overline{\mathrm{x}}=2.39 ; \mathrm{Ss} .=0.89)$ ile erkek adayların ortalamaları $(\overline{\mathrm{x}}=2.63$; Ss.=1.03) arasında erkek öğretmen adaylarının lehine istatistiksel olarak anlamlı bir fark olduğu tespit edilmiştir $\left(\mathrm{t}_{1099}=-3.840 ; \mathrm{p}<0.05\right)$.

- Kişisel bilgisayara sahip olan adaylarının ortalamaları $(\bar{x}=2.52$; Ss. $=0.94)$ ile kişisel bilgisayara sahip olmayan adayların ortalamaları $(\overline{\mathrm{x}}=2.20$; Ss. $=0.94)$ arasında kişisel bilgisayara sahip olanların lehine istatistiksel olarak anlamlı bir fark olduğu tespit edilmiştir $\left(\mathrm{t}_{1099}=4.079 ; \mathrm{p}<0.05\right)$.

- İnternet bağlantısına sahip olan adaylarının ortalamaları $(\bar{x}=2.56$; Ss. $=0.94)$ ile internet bağlantısına sahip olmayan adayların ortalamaları $(\overline{\mathrm{x}}=2.07$; Ss. $=0.83)$ arasında internet bağlantısına sahip olan adayların lehine istatistiksel olarak anlamlı bir fark olduğu tespit edilmiştir $\left(\mathrm{t}_{1099}=6.820 ; \mathrm{p}<0.05\right)$.

Tablo 4. Öğretmen adaylarının dijital medya araçlarından interneti boş zamanlarını değerlendirmek için kullanma süresinin anabilim dalına göre karşılaştırılması

\begin{tabular}{lcccccc}
\hline Varyansın Kaynağı & Kareler Toplamı & Sd. & Kareler Ortalaması & F & p & Fark** \\
\hline Gruplar arası & 40.168 & 11 & 3.652 & & & $2-8,2-9$, \\
Grup içi & 937.872 & 1089 & .861 & 4.240 & $.000 *$ & $2-10,2-11$, \\
Toplam & 978.040 & 1100 & & & & $2-12$ \\
\hline
\end{tabular}

$*: \mathrm{p}<0.05$

**:1-Alman Dili Eğitimi, 2-BÖTE, 3-Coğrafya Eğitimi, 4-Fen Bilgisi Eğitimi, 5-İngiliz Dili Eğitimi, 6-Japon Dili Eğitimi,

7- Müzik Eğitimi, 8-Okul Öncesi Eğitimi, 9-Resim-İs Eğitimi, 10-Sınıf Öğretmenliği, 11-Tarih Eğitimi, 12-Türkçe Eğitimi

Tablo 4, öğretmen adaylarının interneti boş zamanlarını değerlendirmek için kullanma süresi ortalamalarının anabilim dalına göre karşılaştırılmasını göstermektedir. Buna göre öğretmen adaylarının dijital medya araçlarından interneti boş zamanlarını değerlendirmek için haftalık kullanım süresi anabilim dalına göre istatistiksel olarak anlamlı bir farklılık göstermektedir $\left(\mathrm{F}_{11-1089}=4.240\right.$; $\mathrm{p}<0.05)$. Farklılı̆̆ın kaynağını belirlemek için yapılan Tukey testi ile yapılan ikili karşılaştırmalarda; BÖTE bölümünde öğrenim gören ögretmen adayları $(\overline{\mathrm{x}}=2.84$; Ss. $=1.079)$ ile Okul Öncesi Eğitimi 
$(\overline{\mathrm{x}}=2.45$; Ss. $=0.905)$, Resim-İş Eğitimi $(\overline{\mathrm{x}}=2.20$; Ss. $=0.782)$, Sınıf Öğretmenliği Eğitimi $(\overline{\mathrm{x}}=2.25$; Ss.=0.732), Tarih Eğitimi $(\overline{\mathrm{x}}=2.14$; Ss. $=0.707)$ ve Türkçe Eğitimi $(\overline{\mathrm{x}}=2.39$; Ss. $=0.817)$ anabilim dallarında öğrenim gören öğretmen adayları arasında BÖTE öğretmen adaylarının lehine istatistiksel olarak anlamlı bir farklılık olduğu tespit edilmiştir $(\mathrm{p}<0.05)$.

Tablo 5. Öğretmen adaylarının dijital medya araçlarını kitap, dergi ve gazete okumak için kullanma süresinin sınıf, cinsiyet, kişisel bilgisayara sahip olma durumu ve internet bağlantısına sahip olma durumuna göre karşılaş̧tırılması

\begin{tabular}{|c|c|c|c|c|c|c|c|}
\hline & & $\mathbf{f}$ & $\overline{\mathbf{x}}$ & Ss. & $\mathbf{t}$ & Sd. & $\mathbf{p}$ \\
\hline \multirow[t]{2}{*}{ Sinif } & 1 & 551 & 2.22 & .725 & \multirow{2}{*}{-0.124} & \multirow{2}{*}{1091} & \multirow{2}{*}{.901} \\
\hline & 4 & 542 & 2.23 & .746 & & & \\
\hline \multirow{2}{*}{ Cinsiyet } & Kadın & 745 & 2.19 & .721 & \multirow{2}{*}{-2.568} & \multirow{2}{*}{1091} & \multirow{2}{*}{$.010^{*}$} \\
\hline & Erkek & 348 & 2.31 & .759 & & & \\
\hline \multirow[t]{2}{*}{ PC Sahibi Olma } & Evet & 923 & 2.23 & .752 & \multirow{2}{*}{1.034} & \multirow{2}{*}{1091} & \multirow{2}{*}{.301} \\
\hline & Hayır & 170 & 2.17 & .635 & & & \\
\hline \multirow{2}{*}{$\begin{array}{l}\text { İnternet Bağlantısına } \\
\text { Sahip Olma }\end{array}$} & Evet & 893 & 2.23 & .747 & \multirow{2}{*}{0.940} & \multirow{2}{*}{1091} & \multirow{2}{*}{.348} \\
\hline & Hayır & 200 & 2.18 & .678 & & & \\
\hline
\end{tabular}

Tablo 5, öğretmen adaylarının dijital medya araçlarını kitap, dergi ve gazete okumak için haftalık kullanım süresi ortalamalarının sınıf, cinsiyet, kişisel bilgisayara ve internet bağlantısına sahip olma durumuna göre karşılaştırılma sonuçlarını göstermektedir. Buna göre;

- 1. Sinıfta öğrenim gören adaylarının ortalamaları $(\bar{x}=2.22 ; \mathrm{Ss} .=0.73)$ ile 4 . Sinıfta öğrenim gören adayların ortalamaları $(\overline{\mathrm{x}}=2.23$; Ss. $=0.75)$ arasında istatistiksel olarak anlamlı bir fark olmadiğ 1 tespit edilmiştir $\left(\mathrm{t}_{1099}=-0.124 ; \mathrm{p}>0.05\right)$.

- Kadın adaylarının ortalamaları $(\overline{\mathrm{x}}=2.19 ; \mathrm{Ss} .=0.72)$ ile erkek adayların ortalamaları $(\overline{\mathrm{x}}=2.31$; Ss. $=0.76)$ arasında erkek ögretmen adaylarının lehine istatistiksel olarak anlamlı bir fark olduğu tespit edilmiştir $\left(\mathrm{t}_{1099}=-2.568 ; \mathrm{p}<0.05\right)$.

- Kişisel bilgisayara sahip olan adaylarının ortalamaları $(\bar{x}=2.23$; Ss. $=0.75)$ ile kişisel bilgisayara sahip olmayan adayların ortalamaları $(\overline{\mathrm{x}}=2.17$; Ss. $=0.64)$ arasında istatistiksel olarak anlamlı bir fark olmadığ tespit edilmiştir $\left(\mathrm{t}_{1099}=1.034 ; \mathrm{p}>0.05\right)$.

İnternet bağlantısına sahip olan adaylarının ortalamaları $(\overline{\mathrm{x}}=2.23$; Ss. $=0.75)$ ile internet bağlantısına sahip olmayan adayların ortalamaları $(\overline{\mathrm{x}}=2.18$; Ss. $=0.68)$ arasında istatistiksel olarak anlamlı bir fark olmadığ tespit edilmiştir $\left(\mathrm{t}_{1099}=0.940 ; \mathrm{p}>0.05\right)$.

Tablo 6. Öğretmen adaylarının dijital medya araçlarını kitap, dergi ve gazete okumak için kullanma süresinin anabilim dalına göre karşılaştırılması

\begin{tabular}{lccccc}
\hline Varyansın Kaynağı & Kareler Toplamı & Sd. & Kareler Ortalaması & F & p \\
\hline Gruplar arası & 7.436 & 11 & .676 & & \\
Grup içi & 582.646 & 1081 & .539 & 1.254 & .246 \\
Toplam & 590.082 & 1092 & & & \\
\hline
\end{tabular}

Tablo 6, öğretmen adaylarının dijital medya araçlarını kitap, dergi ve gazete okumak için haftalık kullanma süresinin anabilim dalına göre karşılaştırılmasını göstermektedir. Buna göre öğretmen adaylarının dijital medya araçlarını kitap, dergi ve gazete okumak için haftalık kullanım süresinin anabilim dalına göre istatistiksel olarak anlamlı bir farklılık göstermediği tespit edilmiştir $\left(\mathrm{F}_{11-}\right.$ $\left.{ }_{1081}=1.254 ; \mathrm{p}>0.05\right)$. 
Tablo 7. Öğretmen adaylarının dijital medya araçlarından interneti okul ile ilgili işler için kullanma süresinin sınıf, cinsiyet, kişisel bilgisayara sahip olma durumu ve internet bağlantısına sahip olma durumuna göre karşılaştırılması

\begin{tabular}{|c|c|c|c|c|c|c|c|}
\hline & & $\mathbf{f}$ & $\overline{\mathbf{x}}$ & Ss. & $\mathbf{t}$ & Sd. & $\mathbf{p}$ \\
\hline \multirow[t]{2}{*}{ Sinif } & 1 & 555 & 2.08 & .549 & \multirow[b]{2}{*}{-3.399} & \multirow[b]{2}{*}{1099} & \multirow[b]{2}{*}{$.001 *$} \\
\hline & 4 & 546 & 2.21 & .658 & & & \\
\hline \multirow[t]{2}{*}{ Cinsiyet } & Kadın & 751 & 2.16 & .616 & \multirow{2}{*}{1.402} & \multirow{2}{*}{1099} & \multirow{2}{*}{.161} \\
\hline & Erkek & 350 & 2.11 & .591 & & & \\
\hline \multirow[t]{2}{*}{ PC Sahibi Olma } & Evet & 927 & 2.16 & .620 & \multirow{2}{*}{1.691} & \multirow{2}{*}{1099} & \multirow{2}{*}{.091} \\
\hline & Hayır & 174 & 2.07 & .538 & & & \\
\hline \multirow{2}{*}{$\begin{array}{l}\text { İnternet Bağlantısına } \\
\text { Sahip Olma }\end{array}$} & Evet & 897 & 2.17 & .619 & \multirow{2}{*}{2.920} & \multirow{2}{*}{1099} & \multirow{2}{*}{$.004 *$} \\
\hline & Hayır & 204 & 2.03 & .547 & & & \\
\hline
\end{tabular}

Tablo 7, öğretmen adaylarının dijital medya araçlarından interneti okul ile ilgili işler için haftalık kullanım süresi sınıf, cinsiyet, kişisel bilgisayara ve internet bağlantısına sahip olma durumuna göre karşılaştırılma sonuçlarını göstermektedir. Buna göre;

- 1. Sınıfta öğrenim gören adaylarının ortalamaları ( $\bar{x}=2.08 ;$ Ss. $=0.55)$ ile 4. Sınıfta öğrenim gören adayların ortalamaları ( $\overline{\mathrm{x}}=2.21 ; \mathrm{Ss} .=0.66)$ arasında 4 . Sınıfta öğrenim gören adayların lehine istatistiksel olarak anlamlı bir fark olduğu tespit edilmiştir $\left(\mathrm{t}_{1099}=-3.399 ; \mathrm{p}<0.05\right)$.

- Kadın adaylarının ortalamaları $(\bar{x}=2.16$; Ss. $=0.61)$ ile erkek adayların ortalamaları $(\bar{x}=2.11$; Ss. $=0.59)$ arasında istatistiksel olarak anlamlı bir fark olmadığı tespit edilmiştir $\left(\mathrm{t}_{1099}=1.402 ; \mathrm{p}>0.05\right)$.

- Kişisel bilgisayara sahip olan adaylarının ortalamaları $(\bar{x}=2.16$; Ss. $=0.62)$ ile kişisel bilgisayara sahip olmayan adayların ortalamaları $(\overline{\mathrm{x}}=2.07$; Ss. $=0.54)$ arasında istatistiksel olarak anlamlı bir fark olmadığ 1 tespit edilmiştir $\left(\mathrm{t}_{1099}=1.691 ; \mathrm{p}>0.05\right)$.

- İnternet bağlantısına sahip olan adaylarının ortalamaları $(\bar{x}=2.17$; Ss. $=0.62)$ ile internet bağlantısına sahip olmayan adayların ortalamaları $(\overline{\mathrm{x}}=2.03$; Ss. $=0.55)$ arasında internet bağlantısı olan adayların lehine istatistiksel olarak anlamlı bir fark olduğu tespit edilmiştir $\left(\mathrm{t}_{1099}=0.920 ; \mathrm{p}<0.05\right)$.

Tablo 8. Öğretmen adaylarının dijital medya araçlarından interneti okul ile ilgili işler için kullanma süresinin anabilim dalına göre karşı1laştırılması

\begin{tabular}{|c|c|c|c|c|c|c|}
\hline Varyansın Kaynağı & Kareler Toplamı & Sd. & Kareler Ortalaması & $\mathbf{F}$ & $\mathbf{p}$ & Fark** \\
\hline Gruplar arası & 15.754 & 11 & 1.432 & & & $1-7,1-10,1-12$ \\
\hline Grup içi & 391.703 & 1089 & .360 & 3.982 & $.000^{*}$ & $2-7,2-10,5-10$, \\
\hline Toplam & 407.457 & 1100 & & & & 6-7, 6-10 \\
\hline
\end{tabular}

Tablo $8^{`}$ e göre öğretmen adaylarının dijital medya araçlarından interneti okul ile ilgili işler için kullanma süresinin anabilim dalına göre istatistiksel olarak anlamlı bir farklılık gösterdiği tespit edilmiştir $\left(\mathrm{F}_{11-1089}=3.982 ; \mathrm{p}<0.05\right)$. Farlı1ığın kaynağını belirlemek için Tukey testi ile yapılan ikili karş1laştırmalarda;

- Alman Dili Eğitimi anabilim dalında öğrenim gören öğretmen adayları $(\bar{x}=2.39 ;$ Ss. $=0.817)$ ile Müzik Eğitimi ( $\bar{x}=1.92$; Ss.=0.688), Sınıf Öğretmenliği Eğitimi ( $\bar{x}=1.99 ;$ Ss. $=0.304)$ ve Türkçe Eğitimi $(\overline{\mathrm{x}}=2.08$; Ss. $=0.396)$ anabilim dallarında öğrenim gören öğretmen adayları arasında Alman Dili Eğitimi anabilim dalı öğretmen adaylarının lehine,

- BÖTE bölümünde öğrenim gören öğretmen adayları $(\overline{\mathrm{x}}=2.28$; Ss. $=0.764)$ ile Müzik Eğitimi $(\overline{\mathrm{x}}=1.92 ;$ Ss. $=0.688)$ ve Sınıf Öğretmenliği Eğitimi $(\overline{\mathrm{x}}=1.99 ;$ Ss. $=0.304)$ anabilim dallarında 
öğrenim gören öğretmen adayları arasında BÖTE bölümünde öğrenim gören öğretmen adaylarının lehine,

- İngiliz Dili Eğitimi anabilim dalında öğrenim gören öğretmen adayları ( $\bar{x}=2.24$; Ss. $=0.792)$ ile Sınıf Öğretmenliği Eğitimi ( $\bar{x}=1.99$; Ss. $=0.304)$ anabilim dalında öğrenim gören öğretmen adayları arasında İngiliz Dili Eğitimi anabilim dalında öğrenim gören öğretmen adaylarının lehine ve

- Japon Dili Eğitimi anabilim dalında öğrenim gören öğretmen adayları ( $\bar{x}=2.35$; Ss. $=0.686)$ ile Müzik Eğitimi ( $\bar{x}=1.92$; Ss. $=0.688)$ ve Sınıf Öğretmenliği Eğitimi $(\bar{x}=1.99 ;$ Ss.=0.304) anabilim dallarında öğrenim gören öğretmen adayları arasında Japon Dili Eğitimi anabilim dalında öğrenim gören öğretmen adaylarının lehine istatistiksel olarak anlamlı farklılık olduğu tespit edilmiştir $(\mathrm{p}<0.05)$.

Tablo 9. Öğretmen adaylarının dijital medya araçlarını TV seyretmek (internet üzerinden olmayan) için kullanma süresinin sınıf, cinsiyet, kişisel bilgisayara sahip olma durumu ve internet bağlantısına sahip olma durumuna göre karşılaştırılması

\begin{tabular}{|c|c|c|c|c|c|c|c|}
\hline & & f & $\overline{\mathbf{x}}$ & Ss. & $\mathbf{t}$ & Sd. & $\mathbf{p}$ \\
\hline \multirow[t]{2}{*}{$\begin{array}{l}\text { Sinif } \\
\end{array}$} & 1 & 551 & 1.83 & .840 & \multirow{2}{*}{-0.433} & \multirow{2}{*}{1091} & \multirow{2}{*}{.665} \\
\hline & 4 & 542 & 1.85 & .773 & & & \\
\hline \multirow[t]{2}{*}{ Cinsiyet } & Kadın & 743 & 1.77 & .707 & \multirow{2}{*}{-4.049} & \multirow{2}{*}{1091} & \multirow{2}{*}{$.000^{*}$} \\
\hline & Erkek & 350 & 1.98 & .972 & & & \\
\hline \multirow[t]{2}{*}{ PC Sahibi Olma } & Evet & 920 & 1.84 & .774 & \multirow{2}{*}{-0.174} & \multirow{2}{*}{1091} & \multirow{2}{*}{.862} \\
\hline & Hayır & 173 & 1.85 & .965 & & & \\
\hline \multirow{2}{*}{$\begin{array}{l}\text { İnternet Bağlantısına } \\
\text { Sahip Olma }\end{array}$} & Evet & 891 & 1.86 & .782 & \multirow{2}{*}{1.804} & \multirow{2}{*}{1091} & \multirow{2}{*}{.072} \\
\hline & Hayır & 202 & 1.75 & .904 & & & \\
\hline
\end{tabular}

Tablo 9, öğretmen adaylarının dijital medya araçlarından internet üzerinden olmayan televizyon yayınlarını seyretmek için haftalık harcadıkları süre ortalamaların sınıf, cinsiyet, kişisel bilgisayara ve internet bağlantısına sahip olma durumuna göre karşılaştırılma sonuçlarını göstermektedir. Buna göre;

- 1. Sinıfta öğrenim gören adaylarının ortalamaları $(\bar{x}=1.83$; Ss. $=0.84)$ ile 4 . Sinıfta öğrenim gören adayların ortalamaları $(\overline{\mathrm{x}}=1.85 ; \mathrm{Ss} .=0.77)$ arasında istatistiksel olarak anlamlı bir fark olmadığı tespit edilmiştir $\left(\mathrm{t}_{1099}=-0.433 ; \mathrm{p}>0.05\right)$.

- Kadın adaylarının ortalamaları $(\bar{x}=1.77$; Ss. $=0.71)$ ile erkek adayların ortalamaları $(\bar{x}=1.98$; Ss. $=0.97)$ arasında erkek adayların lehine istatistiksel olarak anlamlı bir fark olduğu tespit edilmiştir $\left(\mathrm{t}_{1099}=-4.049 ; \mathrm{p}<0.05\right)$.

- Kişisel bilgisayara sahip olan adaylarının ortalamaları $(\bar{x}=1.84$; Ss.=0.77) ile kişisel bilgisayara sahip olmayan adayların ortalamaları $(\overline{\mathrm{x}}=1.85$; Ss. $=0.97)$ arasında istatistiksel olarak anlamlı bir fark olmadığ 1 tespit edilmiştir $\left(\mathrm{t}_{1099}=0.174 ; \mathrm{p}>0.05\right)$.

- İnternet bağlantısına sahip olan adaylarının ortalamaları ( $\bar{x}=1.86$; Ss. $=0.78)$ ile internet bağlantısına sahip olmayan adayların ortalamaları $(\overline{\mathrm{x}}=1.75$; Ss. $=0.90)$ arasında istatistiksel olarak anlamlı bir fark olmadığ tespit edilmiştir $\left(\mathrm{t}_{1099}=1.804 ; \mathrm{p}>0.05\right)$.

Tablo 10. Öğretmen adaylarının dijital medya araçlarını TV seyretmek (internet üzerinden olmayan) için kullanma süresinin anabilim dalına göre karşılaştırılması

\begin{tabular}{lccccc}
\hline Varyansin Kaynağı & Kareler Toplamı & Sd. & Kareler Ortalaması & F & p \\
\hline Gruplar arası & 12.243 & 11 & 1.113 & & \\
Grup içi & 698.738 & 1081 & .646 & 1.722 & .064 \\
Toplam & 710.981 & 1092 & & & \\
\hline
\end{tabular}


Tablo 10'a göre adaylarının dijital medya araçlarını TV seyretmek (internet üzerinden olmayan) için kullanma süresinin anabilim dalına göre istatistiksel olarak anlamlı bir farklılık göstermediği tespit edilmiştir $\left(\mathrm{F}_{11-1081}=1.722 ; \mathrm{p}>0.05\right)$.

Tablo 11. Öğretmen adaylarının dijital medya araçlarını internet, cep telefonu, PlayStation vb. üzerinden oyun oynamak için kullanma süresinin sınıf, cinsiyet, kişisel bilgisayara sahip olma durumu ve internet bağlantısına sahip olma durumuna göre karșılaștırılması

\begin{tabular}{llcccccc}
\hline & & f & $\overline{\mathbf{x}}$ & Ss. & $\mathbf{t}$ & Sd. & p \\
\hline Sinıf & 1 & 555 & 1.92 & .956 & \multirow{2}{*}{3.225} & \multirow{2}{*}{1096} & $.001^{*}$ \\
Cinsiyet & 4 & 543 & 1.74 & .894 & & & \\
& Kadın & 749 & 1.65 & .807 & -10.165 & 1096 & $.000^{*}$ \\
PC Sahibi Olma & Erkek & 349 & 2.23 & 1.046 & & & \\
& Evet & 925 & 1.83 & .934 & -0.669 & 1096 & .503 \\
İnternet Bağlantısına & Hayır & 173 & 1.88 & .910 & & & \\
Sahip Olma & Evet & 896 & 1.85 & .948 & 1.147 & 1096 & .251 \\
\hline & Hayır & 202 & 1.77 & .847 & & & \\
\hline
\end{tabular}

Tablo 11, öğretmen adaylarının dijital medya araçlarını internet, cep telefonu, Play Station vb. üzerinden oyun oynamak için haftalık harcadıkları süre ortalamalarının sınıf, cinsiyet, kişisel bilgisayara ve internet bağlantısına sahip olma durumuna göre karşılaştırılma sonuçlarını göstermektedir. Buna göre;

- 1. Sınıfta öğrenim gören adaylarının ortalamaları ( $\bar{x}=1.92 ;$ Ss. $=0.96)$ ile 4. Sinıfta öğrenim gören adayların ortalamaları $(\overline{\mathrm{x}}=1.74 ; \mathrm{Ss} .=0.89)$ arasında 1 . Sınıf öğrencilerinin lehine istatistiksel olarak anlamlı bir fark olduğu tespit edilmiştir $\left(t_{1099}=3.225 ; \mathrm{p}<0.05\right)$.

- Kadın adaylarının ortalamaları $(\bar{x}=1.65 ;$ Ss. $=0.81)$ ile erkek adayların ortalamaları $(\bar{x}=2.23$; Ss.=1.1) arasında erkek adayların lehine istatistiksel olarak anlamlı bir fark olduğu tespit edilmiştir $\left(\mathrm{t}_{1099}=-10.165 ; \mathrm{p}<0.05\right)$.

- Kişisel bilgisayara sahip olan adaylarının ortalamaları $(\bar{x}=1.83$; Ss. $=0.88)$ ile kişisel bilgisayara sahip olmayan adayların ortalamaları $(\bar{x}=1.88$; Ss. $=0.91)$ arasında istatistiksel olarak anlamlı bir fark olmadiğ 1 tespit edilmiştir $\left(\mathrm{t}_{1099}=-0.669 ; \mathrm{p}>0.05\right)$.

- İnternet bağlantısına sahip olan adaylarının ortalamaları $(\bar{x}=1.85 ;$ Ss. $=0.95)$ ile internet bağlantısına sahip olmayan adayların ortalamaları $(\overline{\mathrm{x}}=1.77$; Ss. $=0.85)$ arasında istatistiksel olarak anlamlı bir fark olmadığ tespit edilmiştir $\left(\mathrm{t}_{1099}=1.147 ; \mathrm{p}>0.05\right)$.

Tablo 12. Öğretmen adaylarının dijital medya araçlarını internet, cep telefonu, PlayStation vb. üzerinden oyun oynamak için kullanma süresinin anabilim dalına göre karşılaştırılması

\begin{tabular}{lcccccc}
\hline Varyansın Kaynağı & Kareler Toplamı & Sd. & Kareler Ortalaması & F & p & Fark** $^{*}$ \\
\hline Gruplar arası & 30.648 & 11 & 2.786 & & & \\
Grup içi & 918.515 & 1086 & .846 & 3.924 & $.000^{*}$ & $2-3,2-5,2-8$ \\
Toplam & 949.163 & 1097 & & & & \\
\hline
\end{tabular}

*: $\mathrm{p}<0.05$

**:1-Alman Dili Eğitimi, 2-BÖTE, 3-Coğrafya Eğitimi, 4-Fen Bilgisi Eğitimi, 5-İngiliz Dili Eğitimi, 6-Japon Dili Eğitimi,

7- Müzik Eğitimi, 8-Okul Öncesi Eğitimi, 9-Resim-I̦̦ş Eğitimi, 10-Sınıf Öğretmenliği, 11-Tarih Eğitimi, 12-Türkçe Eğitimi

Tablo 12'ye göre öğretmen adaylarının dijital medya araçlarını internet, cep telefonu, PlayStation vb. üzerinden oyun oynamak için kullanma süresinin anabilim dalına göre istatistiksel olarak anlamlı bir farklılık gösterdiği tespit edilmiştir $\left(\mathrm{F}_{11-1086}=3.924\right.$; $\left.\mathrm{p}<0.05\right)$. Farklılığın kaynağını belirlemek için yapılan Tukey testi ile yapılan ikili karşılaştırmalarda; BÖTE bölümünde öğrenim gören öğretmen adayları ( $\overline{\mathrm{x}}=2.18$; Ss. $=1.124)$ ile Coğrafya Eğitimi $(\overline{\mathrm{x}}=1.66$; Ss.=1.758), İngiliz Dili Eğitimi $(\overline{\mathrm{x}}=1.54$; Ss.=0.811) ve Okul Öncesi Eğitimi $(\overline{\mathrm{x}}=1.74$; Ss. $=0.873)$ anabilim dallarında öğrenim gören öğretmen 
adayları arasında BÖTE bölümünde öğrenim gören öğretmen adaylarının lehine istatistiksel olarak anlamlı farklılık olduğu tespit edilmiştir $(\mathrm{p}<0.05)$.

Tablo 13. Öğretmen adaylarının sosyal paylaşım sitelerinde haftalık harcadıkları süre

\begin{tabular}{lccc}
\hline Sosyal Paylaşım Sitesi & $\mathbf{f}$ & $\overline{\mathbf{x}}$ & Ss. \\
\hline Facebook & 1098 & 2.35 & 1.01 \\
YouTube vb. video paylaşım siteleri & 1097 & 2.11 & 0.846 \\
Online gruplar (Google Gruplar, Yahoo gruplar vb.) & 1099 & 1.54 & 0.792 \\
Tek kişilik video oyunları (çevrimiçi, cep telefonu, Play Station vb.) & 1099 & 1.47 & 0.833 \\
Twitter & 1101 & 1.36 & 0.753 \\
Grupla oynanan video oyunları & 1098 & 1.34 & 0.773 \\
Blog kullanımı (Blogspot, Wordpress, Blogger vb.) & 1098 & 1.21 & 0.534 \\
MySpace/Bebo/Friendster vb. diğer sosyal ağlar & 1099 & 1.16 & 0.486 \\
Podcasting/akışlar & 1094 & 1.14 & 0.443 \\
\hline
\end{tabular}

Tablo 13, öğretmen adaylarının sosyal paylaşım sitelerinde haftalık harcadıkları süreyi göstermektedir. Buna göre öğretmen adaylarının en fazla zamanı Facebook ( $\bar{x}=2.35$; Ss.=1.01) daha sonra ise Youtube vb. video paylaşım sitelerinde $(\overline{\mathrm{x}}=2.11$; Ss. $=0.85)$ harcamaktadır. Öğretmen adayları en az zamanı ise podcasting/akışlar ( $\overline{\mathrm{x}}=1.14$; Ss. $=0.44)$ ve MySpace/Bebo/Friendster vb. diğer sosyal ağlarda ( $\overline{\mathrm{x}}=1.16$; Ss. $=0.49)$ harcamaktadır. Bu durum Facebook ve Youtube vb. video paylaşım sitelerinin diğer sosyal ağlara göre daha fazla görsel içerikli olması ve daha eğlenceli olmasından ya da diğer sosyal paylaşım sitelerine nazaran daha popüler olmasından kaynaklanıyor olabilir. Verileri toplamak için kullanılan aracın $1-5$ arasında ( $1=$ Hiç, $2=1-10$ saat, $3=11-20$ saat, $4=21-30$ saat ve $5=30$ saat ve üzeri) ölçme yaptığı dikkate alındığında öğretmen adayları haftalık olarak; Facebook, Youtube vb. video paylaşım siteleri ve çevrimiçi gruplar kategorilerinin her birinde ortalama 1 ile 10 saat arasında zaman harcamaktadır. Twitter, grup video oyunları, blog kullanımı, MySpace/Bebo/Friendster vb. diğer sosyal ağlar ve Podcasting/akışlar kategorilerinin her birinde ise ortalama 1 saatten daha az zaman harcamaktadır.

Tablo 14. Öğretmen adaylarının haftalık Facebook kullanım süresinin sınıf, cinsiyet, kişisel bilgisayara sahip olma durumu ve internet bağlantısına sahip olma durumuna göre karşılaştırılması

\begin{tabular}{llcccccc}
\hline & & f & $\overline{\mathbf{x}}$ & Ss. & $\mathbf{t}$ & Sd. & p \\
\hline Sinıf & 1 & 555 & 2.48 & 1.034 & \multirow{2}{*}{4.362} & 1096 & $.000^{*}$ \\
Cinsiyet & 4 & 543 & 2.22 & .968 & & & \\
& Kadın & 749 & 2.31 & .986 & & & \\
\multirow{2}{*}{ PC Sahibi Olma } & Erkek & 349 & 2.44 & 1.056 & & 1096 & .052 \\
& Evet & 925 & 2.37 & .996 & & & \\
İnternet Bağlantısına & Hayır & 173 & 2.26 & 1.082 & 1.259 & 1096 & .208 \\
Sahip Olma & Evet & 895 & 2.38 & 1.003 & & & \\
& Hayır & 203 & 2.20 & 1.030 & 2.376 & 1096 & $.018^{*}$ \\
\hline
\end{tabular}

*: $\mathrm{p}<0.05$

Tablo 14, öğretmen adaylarının haftalık Facebook kullanım süresinin sınıf, cinsiyet, kişisel bilgisayara sahip olma durumu ve internet bağlantısına sahip olma durumuna göre karşılaştırılma sonuçlarını göstermektedir. Buna göre;

- 1. Sınıfta öğrenim gören adaylarının ortalamaları $(\bar{x}=2.48 ;$ Ss. $=1.034)$ ile 4. Sınıfta öğrenim gören adayların ortalamaları ( $\overline{\mathrm{x}}=2.22$; Ss. $=0.968)$ arasında 1. Sinıfta öğrenim gören öğretmen adaylarının lehine istatistiksel olarak anlamlı bir fark olduğu tespit edilmiştir $\left(\mathrm{t}_{1096}=4.362 ; \mathrm{p}<0.05\right)$. 
- Kadın adaylarının ortalamaları ( $\overline{\mathrm{x}}=2.31$; Ss.=0.986) ile erkek adayların ortalamaları $(\overline{\mathrm{x}}=2.44$; Ss. $=1.056)$ arasında istatistiksel olarak anlamlı bir fark olmadığı tespit edilmiştir $\left(\mathrm{t}_{1096}=-1.944 ; \mathrm{p}>0.05\right)$.

- Kişisel bilgisayara sahip olan adaylarının ortalamaları $(\bar{x}=2.37$; Ss. $=0.996)$ ile kişisel bilgisayara sahip olmayan adayların ortalamaları $(\overline{\mathrm{x}}=2.26$; Ss. $=1.082)$ arasında istatistiksel olarak anlamlı bir fark olmadığ tespit edilmiştir $\left(\mathrm{t}_{1096}=1.259 ; \mathrm{p}>0.05\right)$.

- İnternet bağlantısına sahip olan adaylarının ortalamaları $(\bar{x}=2.38$; Ss.=1.003) ile internet bağlantısına sahip olmayan adayların ortalamaları $(\overline{\mathrm{x}}=2.20 ; \mathrm{Ss} .=1.030)$ arasında internet bağlantısına sahip olan adaylarının lehine istatistiksel olarak anlamlı bir fark olduğu tespit edilmiştir $\left(\mathrm{t}_{1096}=2.376 ; \mathrm{p}<0.05\right)$.

Tablo 15. Öğretmen adaylarının haftalık Facebook kullanım süresinin anabilim dalına göre karş1laştırılması

\begin{tabular}{|c|c|c|c|c|c|c|}
\hline Varyansın Kaynağı & Kareler Toplamı & Sd. & Kareler Ortalaması & $\mathbf{F}$ & $\mathbf{p}$ & Fark** \\
\hline Gruplar arası & 45.173 & 11 & 4.107 & & & $10-2,10-4$, \\
\hline Grup içi & 1074.230 & 1086 & .989 & 4.152 & $.000 *$ & $10-6,10-7$, \\
\hline Toplam & 1119.403 & 1097 & & & & 10-12 \\
\hline
\end{tabular}

Tablo 15, öğretmen adaylarının haftalık Facebook kullanım süresinin anabilim dalına göre karşılaştırılma sonuçlarını göstermektedir. Buna göre öğretmen adaylarının haftalık Facebook kullanım süreleri anabilim dalına göre istatistiksel olarak anlamlı bir farklılık göstermektedir $\left(\mathrm{F}_{11-1086}=4.152\right.$; $\mathrm{p}<0.05)$. Farklılı̆̆ın kaynağını belirlemek için yapılan Tukey testi ile yapılan ikili karşılaştırmalarda; Sınıf Öğretmenliği Eğitimi anabilim dalında öğrenim gören öğretmen adayları ( $\bar{x}=1.96$; Ss. $=0.777$ ) ile BÖTE ( $\bar{x}=2.61$; Ss.=1.002), Fen Bilgisi Eğitimi $(\overline{\mathrm{x}}=2.47$; Ss.=1.193), Japon Dili Eğitimi $(\overline{\mathrm{x}}=2.63$; Ss.=1.070), Müzik Eğitimi ( $\bar{x}=2.63$; Ss.=1.019) ve Türkçe Eğitimi $(\bar{x}=2.38$; Ss.=0.986) anabilim dallarında öğrenim gören öğretmen adayları arasında Sınıf Öğretmenliği Eğitimi anabilim dalında öğrenim gören öğretmen adaylarının aleyhine istatistiksel olarak anlamlı farklılık olduğu tespit edilmiştir $(\mathrm{p}<0.05)$.

Tablo 16. Öğretmen adaylarının YouTube vb. video paylaşım sitelerini haftalık kullanma süresinin sınıf, cinsiyet, kişisel bilgisayara sahip olma durumu ve internet bağlantısına sahip olma durumuna göre karşılaştırılması

\begin{tabular}{|c|c|c|c|c|c|c|c|}
\hline & & $\mathbf{f}$ & $\overline{\mathrm{x}}$ & Ss. & $\mathbf{t}$ & Sd. & $\mathbf{p}$ \\
\hline \multirow[t]{2}{*}{ Sinif } & 1 & 552 & 2.11 & .814 & \multirow{2}{*}{.008} & \multirow{2}{*}{1095} & \multirow{2}{*}{.994} \\
\hline & 4 & 545 & 2.11 & .879 & & & \\
\hline \multirow[t]{2}{*}{ Cinsiyet } & Kadın & 748 & 2.05 & .829 & \multirow{2}{*}{-3.453} & \multirow{2}{*}{1095} & \multirow{2}{*}{$.001 *$} \\
\hline & Erkek & 349 & 2.24 & .871 & & & \\
\hline \multirow[t]{2}{*}{ PC Sahibi Olma } & Evet & 924 & 2.15 & .829 & \multirow{2}{*}{3.881} & \multirow{2}{*}{1095} & \multirow{2}{*}{$.000^{*}$} \\
\hline & Hayır & 173 & 1.88 & .901 & & & \\
\hline \multirow{2}{*}{$\begin{array}{l}\text { İnternet Bağlantısına } \\
\text { Sahip Olma }\end{array}$} & Evet & 896 & 2.16 & .843 & \multirow{2}{*}{3.767} & \multirow{2}{*}{1095} & \multirow{2}{*}{$.028 *$} \\
\hline & Hayır & 203 & 1.91 & .834 & & & \\
\hline
\end{tabular}

Tablo 16, öğretmen adaylarının YouTube vb. video paylaşım sitelerini haftalık kullanma süresinin sınıf, cinsiyet, kişisel bilgisayara sahip olma durumu ve internet bağlantısına sahip olma durumuna göre karşılaştırılma sonuçlarını göstermektedir. Buna göre;

- 1. Sınıfta öğrenim gören adaylarının ortalamaları $(\bar{x}=2.11 ;$ Ss. $=0.814)$ ile 4. Sinıfta öğrenim gören adayların ortalamaları ( $\overline{\mathrm{x}}=2.11$; Ss. $=0.879)$ arasında istatistiksel olarak anlamlı bir fark olmadığ 1 tespit edilmiştir $\left(\mathrm{t}_{1095}=0.008 ; \mathrm{p}>0.05\right)$. 
- Kadın adaylarının ortalamaları $(\overline{\mathrm{x}}=2.05 ; \mathrm{Ss} .=0.829)$ ile erkek adayların ortalamaları $(\overline{\mathrm{x}}=2.24 ;$ Ss. $=0.871)$ arasında erkek öğretmen adaylarının lehine istatistiksel olarak anlamlı bir fark olduğu tespit edilmiştir $\left(\mathrm{t}_{1095}=-3.453\right.$; $\left.\mathrm{p}<0.05\right)$.

- Kişisel bilgisayara sahip olan adaylarının ortalamaları $(\overline{\mathrm{x}}=2.15$; Ss. $=0.829)$ ile kişisel bilgisayara sahip olmayan adayların ortalamaları $(\overline{\mathrm{x}}=1.88$; Ss. $=0.901)$ arasında kişisel bilgisayara sahip olan adayların lehine istatistiksel olarak anlamlı bir fark olduğu tespit edilmiştir $\left(\mathrm{t}_{1095}=3.881 ; \mathrm{p}<0.05\right)$.

- İnternet bağlantısına sahip olan adaylarının ortalamaları $(\overline{\mathrm{x}}=2.16$; Ss. $=0.843)$ ile internet bağlantısına sahip olmayan adayların ortalamaları $(\overline{\mathrm{x}}=1.91$; Ss. $=0.834)$ arasında internet bağlantısına sahip olan adaylarının lehine istatistiksel olarak anlamlı bir fark olduğu tespit edilmiştir $\left(\mathrm{t}_{1095}=3.767 ; \mathrm{p}<0.05\right)$.

Tablo 17. Öğretmen adaylarının YouTube vb. video paylaşım sitelerini haftalık kullanma süresinin anabilim dalına göre karșilaștırılması

\begin{tabular}{|c|c|c|c|c|c|c|}
\hline Varyansın Kaynağı & Kareler Toplamı & Sd. & Kareler Ortalaması & $\mathbf{F}$ & $\mathbf{p}$ & Fark** \\
\hline Gruplar arası & 30.470 & 11 & 2.770 & & & \\
\hline Grup içi & 754.739 & 1085 & .696 & 3.982 & .000 & $\begin{array}{c}7-3,7-10,7-11, \\
7-12,2-10\end{array}$ \\
\hline Toplam & 785.209 & 1096 & & & & \\
\hline
\end{tabular}

Tablo 17, öğretmen adaylarının YouTube vb. video paylaşım sitelerini haftalık kullanma süresinin anabilim dalına göre sonuçlarını göstermektedir. Buna göre öğretmen adaylarının YouTube vb. video paylaşım sitelerini haftalık kullanma süresi anabilim dalına göre istatistiksel olarak anlamlı bir farklılık göstermektedir $\left(\mathrm{F}_{11-1085}=3.982 ; \mathrm{p}<0.05\right)$. Farklılığın kaynağını belirlemek için yapılan Tukey testi ile yapılan ikili karşılaştırmalarda; Müzik Eğitimi anabilim dalında öğrenim gören öğretmen adayları ( $\overline{\mathrm{x}}=2.53$; Ss.=1.084) ile Coğrafya Eğitimi $(\overline{\mathrm{x}}=1.96$; Ss. $=0.678)$, Sinıf Öğretmenliği Eğitimi $(\overline{\mathrm{x}}=1.89$; Ss. $=0.630)$, Tarih Eğitimi $(\overline{\mathrm{x}}=1.90 ;$ Ss. $=0.660)$ ve Türkçe Eğitimi $(\overline{\mathrm{x}}=2.03 ;$ Ss. $=0.870)$ anabilim dallarında öğrenim gören öğretmen adayları arasında Müzik Eğitimi anabilim dalında öğrenim gören öğretmen adaylarının lehine istatistiksel olarak anlamlı farklılık olduğu ve BÖTE $(\overline{\mathrm{x}}=2.36$; Ss.=0.990) ile Sınıf Öğretmenliği Eğitimi $(\overline{\mathrm{x}}=1.89$; Ss. $=0.630)$ arasında BÖTE adaylarının lehine istatistiksel olarak anlamlı farklılık olduğu tespit edilmiştir $(\mathrm{p}<0.05)$.

Tablo 18. Öğretmen adaylarının Google, Yahoo vb. çevrimiçi grupları haftalık kullanma süresinin sınıf, cinsiyet, kişisel bilgisayara sahip olma durumu ve internet bağlantısına sahip olma durumuna göre karşıllaştırılması

\begin{tabular}{|c|c|c|c|c|c|c|c|}
\hline & & $\mathbf{f}$ & $\overline{\mathbf{x}}$ & Ss. & $\mathbf{t}$ & Sd. & $\mathbf{p}$ \\
\hline \multirow[t]{2}{*}{ Sinif } & 1 & 553 & 1.59 & .822 & \multirow{2}{*}{2.490} & \multirow{2}{*}{1097} & \multirow{2}{*}{$.013 *$} \\
\hline & 4 & 546 & 1.48 & .757 & & & \\
\hline \multirow[t]{2}{*}{ Cinsiyet } & Kadın & 749 & 1.51 & .765 & \multirow{2}{*}{-1.834} & \multirow{2}{*}{1097} & \multirow{2}{*}{.067} \\
\hline & Erkek & 350 & 1.60 & .846 & & & \\
\hline \multirow[t]{2}{*}{ PC Sahibi Olma } & Evet & 925 & 1.52 & .780 & \multirow{2}{*}{-1.225} & \multirow{2}{*}{1097} & \multirow{2}{*}{.221} \\
\hline & Hayır & 174 & 1.60 & .852 & & & \\
\hline \multirow{2}{*}{$\begin{array}{l}\text { İnternet Bağlantısına } \\
\text { Sahip Olma }\end{array}$} & Evet & 895 & 1.55 & .816 & \multirow{2}{*}{1.600} & \multirow{2}{*}{1097} & \multirow{2}{*}{.110} \\
\hline & Hayır & 204 & 1.46 & .675 & & & \\
\hline
\end{tabular}

*: $\mathrm{p}<0.05$

Tablo 18 öğretmen adaylarının Google, Yahoo vb. çevrimiçi grupları haftalık kullanma süresinin sınıf, cinsiyet, kişisel bilgisayara sahip olma durumu ve internet bağlantısına sahip olma durumuna göre karşılaştırılma sonuçlarını göstermektedir. Buna göre;

- 1. Sınıfta öğrenim gören adaylarının ortalamaları $(\bar{x}=1.59 ;$ Ss. $=0.822)$ ile 4. Sınıfta öğrenim gören adayların ortalamaları $(\overline{\mathrm{x}}=1.48 ; \mathrm{Ss} .=0.757)$ arasında 1. Sınıfta öğrenim gören 
öğretmen adaylarının lehine istatistiksel olarak anlamlı bir fark olduğu tespit edilmiştir $\left(\mathrm{t}_{1097}=2.490 ; \mathrm{p}<0.05\right)$.

- Kadın adaylarının ortalamaları $(\overline{\mathrm{x}}=1.51$; Ss. $=0.765)$ ile erkek adayların ortalamaları $(\overline{\mathrm{x}}=1.60 ;$ Ss. $=0.846)$ arasında istatistiksel olarak anlamlı bir fark olmadığı tespit edilmiştir $\left(\mathrm{t}_{1097}=-1.834 ; \mathrm{p}>0.05\right)$.

- Kişisel bilgisayara sahip olan adaylarının ortalamaları $(\bar{x}=1.52$; Ss. $=0.780)$ ile kişisel bilgisayara sahip olmayan adayların ortalamaları $(\overline{\mathrm{x}}=1.60 ; \mathrm{Ss} .=0.852)$ arasında istatistiksel olarak anlamlı bir fark olmadığ 1 tespit edilmiştir $\left(\mathrm{t}_{1097}=-1.225 ; \mathrm{p}>0.05\right)$.

- İnternet bağlantısına sahip olan adaylarının ortalamaları $(\overline{\mathrm{x}}=1.55$; Ss. $=0.816)$ ile internet bağlantısına sahip olmayan adayların ortalamaları $(\overline{\mathrm{x}}=1.46 ; \mathrm{Ss} .=0.6750)$ arasında istatistiksel olarak anlamlı bir fark olmadığı tespit edilmiştir $\left(\mathrm{t}_{1097}=1.600 ; \mathrm{p}>0.05\right)$.

Tablo 19. Öğretmen adaylarının Google, Yahoo vb. çevrimiçi grupları haftalık kullanma süresinin anabilim dalına göre karșılaștırılması

\begin{tabular}{lccccc}
\hline Varyansın Kaynağı & Kareler Toplamı & Sd. & Kareler Ortalaması & F & p \\
\hline Gruplar arası & 7.735 & 11 & .703 & & \\
Grup içi & 681.595 & 1087 & .627 & 1.121 & .340 \\
Toplam & 689.330 & 1098 & & & \\
\hline
\end{tabular}

Tablo 19, öğretmen adaylarının Google, Yahoo vb. çevrimiçi grupları haftalık kullanma süresinin anabilim dalına göre karşılaştırılma sonuçlarını göstermektedir. Buna göre öğretmen adaylarının Google, Yahoo vb. çevrimiçi grupları haftalık kullanma süresi anabilim dalına göre istatistiksel olarak anlamlı bir farkl1lık göstermemektedir $\left(\mathrm{F}_{11-1087}=1.121 ; \mathrm{p}>0.05\right)$.

Tablo 20. Öğretmen adaylarının tek kişilik video oyunlarını haftalık kullanma süresinin sınıf, cinsiyet, kişisel bilgisayara sahip olma durumu ve internet bağlantısına sahip olma durumuna göre karşılaştırılması

\begin{tabular}{llcccccc}
\hline & & $\mathbf{f}$ & $\overline{\mathbf{x}}$ & Ss. & $\mathbf{t}$ & Sd. & p \\
\hline Sinıf & 1 & 554 & 1.52 & .904 & \multirow{2}{*}{1.766} & \multirow{2}{*}{1097} & .078 \\
Cinsiyet & 4 & 545 & 1.43 & .752 & & & \\
& Kadın & 749 & 1.29 & .633 & -11.338 & 1097 & $.000^{*}$ \\
PC Sahibi Olma & Erkek & 350 & 1.87 & 1.046 & & & \\
& Evet & 925 & 1.45 & .801 & -1.938 & 1097 & .053 \\
İnternet Bağlantısına & Hayır & 174 & 1.59 & .980 & & & \\
Sahip Olma & Evet & 895 & 1.48 & .840 & .159 & 1097 & .874 \\
\hline *:p<0.05 & Hayır & 204 & 1.47 & .803 & & &
\end{tabular}

Tablo 20, öğretmen adaylarının tek kişilik video oyunlarını haftalık kullanma süresinin sınıf, cinsiyet, kişisel bilgisayara sahip olma durumu ve internet bağlantısına sahip olma durumuna göre karşılaştırılma sonuçlarını göstermektedir. Buna göre;

- 1. Sınıfta öğrenim gören adaylarının ortalamaları $(\bar{x}=1.52 ;$ Ss. $=0.904)$ ile 4. Sınıfta öğrenim gören adayların ortalamaları $(\overline{\mathrm{x}}=1.43$; Ss. $=0.752)$ arasında istatistiksel olarak anlamlı bir fark olmadı $\breve{g}$ tespit edilmiştir $\left(\mathrm{t}_{1097}=1.766 ; \mathrm{p}>0.05\right)$.

- Kadın adaylarının ortalamaları ( $\bar{x}=1.29 ;$ Ss.=0.633) ile erkek adayların ortalamaları $(\overrightarrow{\mathrm{x}}=1.87$; Ss. $=1.046)$ arasında erkek adayların lehine istatistiksel olarak anlamlı bir fark olduğu tespit edilmiştir $\left(\mathrm{t}_{1097}=-11.338 ; \mathrm{p}<0.05\right)$.

- Kişisel bilgisayara sahip olan adaylarının ortalamaları $(\overline{\mathrm{x}}=1.45$; Ss. $=0.801)$ ile kişisel bilgisayara sahip olmayan adayların ortalamaları $(\overline{\mathrm{x}}=1.59$; Ss. $=0.980)$ arasında istatistiksel olarak anlamlı bir fark olmadığ tespit edilmiştir $\left(\mathrm{t}_{1097}=-1.938 ; \mathrm{p}>0.05\right)$. 
- İnternet bağlantısına sahip olan adaylarının ortalamaları $(\overline{\mathrm{x}}=1.48$; Ss. $=0.840)$ ile internet bağlantısına sahip olmayan adayların ortalamaları $(\overline{\mathrm{x}}=1.47 ; \mathrm{Ss} .=0.903)$ arasında istatistiksel olarak anlamlı bir fark olmadığ

Tablo 21. Öğretmen adaylarının tek kişilik video oyunlarını haftalık kullanma süresinin anabilim dalına göre karşılaştırılması

\begin{tabular}{lccccc}
\hline Varyansın Kaynağı & Kareler Toplamı & Sd. & Kareler Ortalaması & F & p \\
\hline Gruplar arası & 8.275 & 11 & .752 & & \\
Grup içi & 753.736 & 1087 & .693 & 1.085 & .370 \\
Toplam & 762.011 & 1098 & & & \\
\hline
\end{tabular}

Tablo 21, öğretmen adaylarının tek kişilik video oyunlarını haftalık kullanma süresinin anabilim dalına göre karşılaştırılma sonuçlarını göstermektedir. Buna göre öğretmen adaylarının tek kişilik video oyunlarını haftalık kullanma süresi anabilim dalına göre istatistiksel olarak anlamlı bir farklılık göstermemektedir $\left(\mathrm{F}_{11-1087}=1.085 ; \mathrm{p}>0.05\right)$.

Tablo 22. Öğretmen adaylarının haftalık Twitter kullanma süresinin sınıf, cinsiyet, kişisel bilgisayara sahip olma durumu ve internet bağlantısına sahip olma durumuna göre karşılaştırılması

\begin{tabular}{llcccccc}
\hline & & f & $\overline{\mathbf{x}}$ & Ss. & t & Sd. & p \\
\hline Sinıf & 1 & 555 & 1.34 & .749 & \multirow{2}{*}{-.810} & 1099 & .418 \\
Cinsiyet & 4 & 546 & 1.38 & .757 & & & \\
& Kadın & 751 & 1.32 & .740 & -2.797 & 1099 & $.005^{*}$ \\
PC Sahibi Olma & Erkek & 350 & 1.45 & .773 & & & \\
& Evet & 927 & 1.39 & .785 & 3.132 & 1099 & $.002^{*}$ \\
İnternet Bağlantısına & Hayır & 174 & 1.20 & .523 & & & \\
Sahip Olma & Evet & 897 & 1.39 & .776 & \multirow{2}{*}{2.810} & 1099 & $.005^{*}$ \\
\hline
\end{tabular}

*: $\mathrm{p}<0.05$

Tablo 22, öğretmen adaylarının haftalık Twitter kullanma süresinin sınıf, cinsiyet, kişisel bilgisayara sahip olma durumu ve internet bağlantısına sahip olma durumuna göre karşılaştırılma sonuçlarını göstermektedir. Buna göre;

- 1. Sınıfta öğrenim gören adaylarının ortalamaları $(\bar{x}=1.34 ;$ Ss. $=0.749)$ ile 4. Sınıfta öğrenim gören adayların ortalamaları $(\overline{\mathrm{x}}=1.38$; $\mathrm{Ss} .=0.757)$ arasında istatistiksel olarak anlamlı bir fark olmadı̆ 1 tespit edilmiştir $\left(\mathrm{t}_{1099}=-0.810 ; \mathrm{p}>0.05\right)$.

- Kadın adaylarının ortalamaları ( $\overline{\mathrm{x}}=1.32$; Ss. $=0.740)$ ile erkek adayların ortalamaları $(\overline{\mathrm{x}}=1.45$; Ss. $=0.773)$ arasında erkek adayların lehine istatistiksel olarak anlamlı bir fark olduğu tespit edilmiştir $\left(\mathrm{t}_{1099}=-2.797 ; \mathrm{p}<0.05\right)$.

- Kişisel bilgisayara sahip olan adaylarının ortalamaları $(\bar{x}=1.39$; Ss.=0.785) ile kişisel bilgisayara sahip olmayan adayların ortalamaları $(\overline{\mathrm{x}}=1.20$; Ss. $=0.523)$ arasında kişisel bilgisayara sahip olanların lehine istatistiksel olarak anlamlı bir fark olduğu tespit edilmiştir $\left(\mathrm{t}_{1099}=3.132 ; \mathrm{p}<0.05\right)$.

- İnternet bağlantısına sahip olan adaylarının ortalamaları $(\bar{x}=1.39$; Ss. $=0.776)$ ile internet bağlantısına sahip olmayan adayların ortalamaları $(\overline{\mathrm{x}}=1.23$; Ss. $=0.626)$ arasında internet bağlantısına sahip olan adaylarının lehine istatistiksel olarak anlamlı bir fark olduğu tespit edilmiştir $\left(\mathrm{t}_{1099}=2.810 ; \mathrm{p}<0.05\right)$. 
Tablo 23. Öğretmen adaylarının haftalık Twitter kullanma süresinin anabilim dalına göre karşı1laştırılması

\begin{tabular}{|c|c|c|c|c|c|}
\hline Varyansın Kaynağı & Kareler Toplamı & Sd. & Kareler Ortalaması & $\mathbf{F}$ & $\mathbf{p}$ \\
\hline Gruplar arası & 5.819 & 11 & .529 & & \\
\hline Grup içi & 617.469 & 1089 & .567 & .933 & .507 \\
\hline Toplam & 623.288 & 1100 & & & \\
\hline
\end{tabular}

Tablo 23, öğretmen adaylarının haftalık Twitter kullanma süresinin anabilim dalına göre karşılaştırılma sonuçlarını göstermektedir. Buna göre öğretmen adaylarının haftalık Twitter kullanım süreleri anabilim dalına göre istatistiksel olarak anlamlı bir farklılık göstermemektedir $\left(\mathrm{F}_{11-1089}=0.933\right.$; $\mathrm{p}>0.05)$.

Tablo 24. Öğretmen adaylarının grupla oynanan oyunları haftalık kullanma süresinin sınıf, cinsiyet, kişisel bilgisayara sahip olma durumu ve internet bağlantısına sahip olma durumuna göre karșilaştırılması

\begin{tabular}{|c|c|c|c|c|c|c|c|}
\hline & & f & $\overline{\mathbf{x}}$ & Ss. & $\mathbf{t}$ & Sd. & $\mathbf{p}$ \\
\hline \multirow[t]{2}{*}{ Sinıf } & 1 & 552 & 1.39 & .851 & \multirow{2}{*}{1.953} & \multirow{2}{*}{1096} & \multirow{2}{*}{.051} \\
\hline & 4 & 546 & 1.30 & .683 & & & \\
\hline \multirow[t]{2}{*}{ Cinsiyet } & Kadın & 749 & 1.12 & .446 & \multirow{2}{*}{-15.165} & \multirow{2}{*}{1096} & \multirow{2}{*}{$.000^{*}$} \\
\hline & Erkek & 349 & 1.81 & 1.063 & & & \\
\hline \multirow[t]{2}{*}{ PC Sahibi Olma } & Evet & 925 & 1.33 & .749 & \multirow{2}{*}{-1.690} & \multirow{2}{*}{1096} & \multirow{2}{*}{.091} \\
\hline & Hayır & 173 & 1.43 & .884 & & & \\
\hline \multirow{2}{*}{$\begin{array}{l}\text { İnternet Bağlantısına } \\
\text { Sahip Olma }\end{array}$} & Evet & 894 & 1.34 & .784 & \multirow{2}{*}{-.215} & \multirow{2}{*}{1096} & \multirow{2}{*}{.830} \\
\hline & Hayır & 204 & 1.35 & .725 & & & \\
\hline
\end{tabular}

*: $\mathrm{p}<0.05$

Tablo 24, öğretmen adaylarının grupla oynanan oyunları haftalık kullanma süresinin sınıf, cinsiyet, kişisel bilgisayara sahip olma durumu ve internet bağlantısına sahip olma durumuna göre karşılaştırılma sonuçlarını göstermektedir. Buna göre;

- 1. Sınıfta öğrenim gören adaylarının ortalamaları $(\bar{x}=1.39 ;$ Ss. $=0.851)$ ile 4. Sınıfta öğrenim gören adayların ortalamaları $(\overline{\mathrm{x}}=1.30$; Ss. $=0.683)$ arasında istatistiksel olarak anlamlı bir fark olmadığ

- Kadın adaylarının ortalamaları $(\bar{x}=1.12$; Ss.=0.446) ile erkek adayların ortalamaları $(\overline{\mathrm{x}}=1.81$; Ss. $=1.063)$ arasında erkek adayların lehine istatistiksel olarak anlamlı bir fark olduğu tespit edilmiştir $\left(\mathrm{t}_{1096}=-15.165 ; \mathrm{p}<0.05\right)$.

- Kişisel bilgisayara sahip olan adaylarının ortalamaları $(\bar{x}=1.33$; Ss. $=0.749)$ ile kişisel bilgisayara sahip olmayan adayların ortalamaları $(\overline{\mathrm{x}}=1.43$; Ss. $=0.884)$ arasında istatistiksel olarak anlamlı bir fark olmadı $\breve{g} 1$ tespit edilmiştir $\left(\mathrm{t}_{1096}=-1.690 ; \mathrm{p}>0.05\right)$.

- İnternet bağlantısına sahip olan adaylarının ortalamaları $(\bar{x}=1.34$; Ss. $=0.784)$ ile internet bağlantısına sahip olmayan adayların ortalamaları $(\bar{x}=1.35 ;$ Ss. $=0.725)$ arasında istatistiksel olarak anlamlı bir fark olmadığ 1 tespit edilmiştir $\left(\mathrm{t}_{1096}=-0.215 ; \mathrm{p}>0.05\right)$.

Tablo 25. Öğretmen adaylarının grupla oynanan oyunları haftalık kullanma süresinin anabilim dalına göre karşılaştırılması

\begin{tabular}{lcccccc}
\hline Varyansın Kaynağı & Kareler Toplamı & Sd. & Kareler Ortalaması & F & p & Fark** \\
\hline Gruplar arası & 15.510 & 11 & 1.410 & & & \\
Grup içi & 639.732 & 1086 & .589 & 2.394 & $.006^{*}$ & $2-1,2-8,2-10$ \\
Toplam & 655.242 & 1097 & & & & \\
\hline
\end{tabular}

$*: \mathrm{p}<0.05$

**:1-Alman Dili Eğitimi, 2-BÖTE, 3-Coğrafya Eğitimi, 4-Fen Bilgisi Eğitimi, 5-İngiliz Dili Eğitimi, 6-Japon Dili Eğitimi,

7- Müzik Eğitimi, 8-Okul Öncesi Eğitimi, 9-Resim-I̦ş Eğitimi, 10-Sınıf Öğretmenliği, 11-Tarih Eğitimi, 12-Türkçe Eğitimi 
Tablo 25, öğretmen adaylarının grupla oynanan oyunları haftalık kullanma süresinin anabilim dalına göre karşılaştırılma sonuçlarını göstermektedir. Buna göre öğretmen adaylarının grupla oynanan oyunları haftalık kullanma süreleri anabilim dalına göre istatistiksel olarak anlamlı bir farklılık göstermektedir $\left(\mathrm{F}_{11-1086}=2.394 ; \mathrm{p}<0.05\right)$. Farklılığın kaynağını belirlemek için yapılan Tukey testi ile yapılan ikili karşılaştırmalarda; BÖTE'de öğrenim gören öğretmen adayları ( $\bar{x}=1.58$; Ss. $=0.988)$ ile Alman Dili Eğitimi ( $\bar{x}=1.16$; Ss. $=0.606)$, Okul Öncesi Eğitimi $(\bar{x}=1.24 ;$ Ss. $=0.650)$ ve Sinıf Öğretmenliği Eğitimi ( $\bar{x}=1.27$; Ss. $=0.611)$ anabilim dallarında öğrenim gören öğretmen adayları arasında BÖTE'de öğrenim gören ögretmen adaylarının lehine istatistiksel olarak anlamlı farklılık olduğu tespit edilmiştir $(\mathrm{p}<0.05)$.

Tablo 26. Öğretmen adaylarının Blogspot, Wordpress, Blogger vb. blog sitelerini haftalık kullanma süresinin sınıf, cinsiyet, kişisel bilgisayara sahip olma durumu ve internet bağlantısına sahip olma durumuna göre karşılaştırılması

\begin{tabular}{llcccccc}
\hline & & $\mathbf{f}$ & $\overline{\mathbf{x}}$ & Ss. & $\mathbf{t}$ & Sd. & p \\
\hline Sinıf & 1 & 552 & 1.17 & .517 & \multirow{2}{*}{.505} & \multirow{2}{*}{1096} & $.012^{*}$ \\
& 4 & 546 & 1.25 & .549 & & & \\
Cinsiyet & Kadın & 748 & 1.17 & .480 & -3.410 & 1096 & $.001^{*}$ \\
& Erkek & 350 & 1.29 & .628 & & & \\
PC Sahibi Olma & Evet & 924 & 1.22 & .553 & \multirow{2}{*}{1.437} & 1096 & .151 \\
& Hayır & 174 & 1.16 & .422 & & & \\
İnternet Bağlantısına & Evet & 894 & 1.22 & .551 & \multirow{2}{*}{1.824} & \multirow{2}{*}{1096} & .068 \\
Sahip Olma & Hayır & 204 & 1.15 & .453 & & &
\end{tabular}

Tablo 26, öğretmen adaylarının Blogspot, Wordpress, Blogger vb. blog sitelerini haftalık kullanma süresinin sınıf, cinsiyet, kişisel bilgisayara sahip olma durumu ve internet bağlantısına sahip olma durumuna göre karşılaştırılma sonuçlarını göstermektedir. Buna göre;

- 1. Sinıfta öğrenim gören adaylarının ortalamaları $(\bar{x}=1.17 ;$ Ss. $=0.517)$ ile 4. Sinıfta öğrenim gören adayların ortalamaları $(\bar{x}=1.25 ;$ Ss. $=0.549)$ arasında 4 . Sinıfta öğrenim gören öğretmen adaylarının lehine istatistiksel olarak anlamlı bir fark olduğu tespit edilmiştir $\left(\mathrm{t}_{1096}=-2.505 ; \mathrm{p}<0.05\right)$.

- Kadın adaylarının ortalamaları ( $\bar{x}=1.17 ;$ Ss.=0.480) ile erkek adayların ortalamaları $(\overline{\mathrm{x}}=1.29$; Ss. $=0.628)$ arasında erkek adayların lehine istatistiksel olarak anlamlı bir fark olduğu tespit edilmiştir $\left(\mathrm{t}_{1096}=-3.410 ; \mathrm{p}<0.05\right)$.

- Kişisel bilgisayara sahip olan adaylarının ortalamaları $(\overline{\mathrm{x}}=1.22$; Ss. $=0.553)$ ile kişisel bilgisayara sahip olmayan adayların ortalamaları $(\overline{\mathrm{x}}=1.16$; $\mathrm{Ss} .=0.422)$ arasında istatistiksel olarak anlamlı bir fark olmadığ tespit edilmiştir $\left(\mathrm{t}_{1096}=1.437 ; \mathrm{p}>0.05\right)$.

- İnternet bağlantısına sahip olan adaylarının ortalamaları $(\bar{x}=1.22$; Ss. $=0.551)$ ile internet bağlantısına sahip olmayan adayların ortalamaları $(\overline{\mathrm{x}}=1.15 ; \mathrm{Ss} .=0.453)$ arasında istatistiksel olarak anlamlı bir fark olmadığ tespit edilmiştir $\left(\mathrm{t}_{1096}=1.824 ; \mathrm{p}>0.05\right)$.

Tablo 27. Öğretmen adaylarının Blogspot, Wordpress, Blogger vb. blog sitelerini haftalık kullanma süresinin anabilim dalına göre karşılaştırılması

\begin{tabular}{|c|c|c|c|c|c|c|}
\hline Varyansın Kaynağı & Kareler Toplamı & Sd. & Kareler Ortalaması & $\mathbf{F}$ & $\mathbf{p}$ & Fark** \\
\hline Gruplar arası & 11.038 & 11 & 1.003 & & & $2-1,2-3,2-4$ \\
\hline Grup içi & 302.202 & 1086 & .278 & 3.606 & .000 & $2-6,2-8,2-10$, \\
\hline Toplam & 313.240 & 1097 & & & & $2-11,2-12$ \\
\hline
\end{tabular}

Tablo 27, öğretmen adaylarının Blogspot, Wordpress, Blogger vb. blog sitelerini haftalık kullanma süresinin anabilim dalına göre karşılaştırılma sonuçlarını göstermektedir. Buna göre öğretmen 
adaylarının Blogspot, Wordpress, Blogger vb. blog sitelerini haftalık kullanma süresi anabilim dalına göre istatistiksel olarak anlamlı bir farkl11ık göstermektedir $\left(F_{11-1086}=3.606 ; p<0.05\right)$. Farkl11ı̆̆n kaynağını belirlemek için yapılan Tukey testi ile yapılan ikili karşılaştırmalarda; BÖTE'de öğrenim gören öğretmen adayları ( $\overline{\mathrm{x}}=1.43$; Ss. $=0.763)$ ile Alman Dili Eğitimi $(\overline{\mathrm{x}}=1.10$; Ss. $=0.298)$, Coğrafya Eğitimi ( $\overline{\mathrm{x}}=1.08$; Ss.=0.267), Fen Bilgisi Eğitimi $(\overline{\mathrm{x}}=1.14$; Ss.=0.476), Japon Dili Eğitimi $(\overline{\mathrm{x}}=1.12$; Ss.=0.391), Müzik Eğitimi ( $\overline{\mathrm{x}}=1.31$; Ss. $=0.678)$, Okul Öncesi Eğitimi $(\overline{\mathrm{x}}=1.20$; Ss. $=0.556)$, Sınıf Öğretmenliği Eğitimi ( $\bar{x}=1.20$; Ss.=0.548), Tarih Eğitimi $(\bar{x}=1.12$; Ss.=0.331) ve Türkçe Eğitimi $(\overline{\mathrm{x}}=1.21$; Ss. $=0.534)$ anabilim dallarında öğrenim gören öğretmen adayları arasında BÖTE'de öğrenim gören öğretmen adaylarının lehine istatistiksel olarak anlamlı farklılık olduğu tespit edilmiştir $(p<0.05)$.

Tablo 28. Öğretmen adaylarının MySpace, Bebo, Friendster vb. diğer sosyal ağları haftalık kullanma süresinin sınıf, cinsiyet, kişisel bilgisayara sahip olma durumu ve internet bağlantısına sahip olma durumuna göre karşılaştırılması

\begin{tabular}{llcccccc}
\hline & & f & $\overline{\mathbf{x}}$ & Ss. & t & Sd. & p \\
\hline Sinıf & 1 & 554 & 1.15 & .456 & \multirow{2}{*}{-1.804} & 1097 & .279 \\
Cinsiyet & 4 & 545 & 1.18 & .514 & & & \\
& Kadın & 749 & 1.14 & .476 & -1.910 & 1097 & .056 \\
PC Sahibi Olma & Erkek & 350 & 1.20 & .504 & & & \\
& Evet & 926 & 1.17 & .510 & 1.881 & 1097 & .060 \\
İnternet Bağlantısına & Hayır & 173 & 1.10 & .317 & & & \\
Sahip Olma & Evet & 895 & 1.17 & .505 & \multirow{2}{*}{1.605} & 1097 & .109 \\
\hline
\end{tabular}

*: $\mathrm{p}<0.05$

Tablo 28, öğretmen adaylarının MySpace, Bebo, Friendster vb. diğer sosyal ağları haftalık kullanma süresinin sınıf, cinsiyet, kişisel bilgisayara sahip olma durumu ve internet bağlantısına sahip olma durumuna göre karşılaştırılma sonuçlarını göstermektedir. Buna göre;

- 1. Sınıfta öğrenim gören adaylarının ortalamaları $(\bar{x}=1.15 ;$ Ss. $=0.456)$ ile 4. Sınıfta öğrenim gören adayların ortalamaları $(\overline{\mathrm{x}}=1.18$; Ss. $=0.514)$ arasında istatistiksel olarak anlamlı bir fark olmadı̆̆ tespit edilmiştir $\left(\mathrm{t}_{1097}=-1.804 ; \mathrm{p}>0.05\right)$.

- Kadın adaylarının ortalamaları ( $\bar{x}=1.14$; Ss.=0.476) ile erkek adayların ortalamaları $(\overline{\mathrm{x}}=1.20 ; \mathrm{Ss} .=0.504)$ arasında istatistiksel olarak anlamlı bir fark olmadığı tespit edilmiştir $\left(\mathrm{t}_{1097}=-1.910 ; \mathrm{p}>0.05\right)$.

- Kişisel bilgisayara sahip olan adaylarının ortalamaları $(\bar{x}=1.17$; Ss.=0.510) ile kişisel bilgisayara sahip olmayan adayların ortalamaları $(\overline{\mathrm{x}}=1.10 ;$ Ss. $=0.317)$ arasında istatistiksel olarak anlamlı bir fark olmadığ tespit edilmiştir $\left(\mathrm{t}_{1097}=1.881 ; \mathrm{p}>0.05\right)$.

- İnternet bağlantısına sahip olan adaylarının ortalamaları $(\bar{x}=1.17$; Ss. $=0.505)$ ile internet bağlantısına sahip olmayan adayların ortalamaları $(\overline{\mathrm{x}}=1.11$; Ss. $=0.387)$ arasında istatistiksel olarak anlamlı bir fark olmadığı tespit edilmiştir $\left(\mathrm{t}_{1097}=1.605 ; \mathrm{p}>0.05\right)$.

Tablo 29. Öğretmen adaylarının MySpace, Bebo, Friendster vb. diğer sosyal ağları haftalık kullanma süresinin anabilim dalına göre karşılaştırılması

\begin{tabular}{|c|c|c|c|c|c|}
\hline Varyansın Kaynağı & Kareler Toplamı & Sd. & Kareler Ortalaması & $\mathbf{F}$ & $\mathbf{p}$ \\
\hline Gruplar arası & 2.546 & 11 & .231 & & \\
\hline Grup içi & 256.624 & 1087 & .236 & .980 & .462 \\
\hline Toplam & 259.170 & 1098 & & & \\
\hline
\end{tabular}

Tablo 29, öğretmen adaylarının MySpace, Bebo, Friendster vb. diğer sosyal ağları haftalık kullanma süresinin anabilim dalına göre karşılaştırılma sonuçlarını göstermektedir. Buna göre öğretmen adaylarının MySpace, Bebo, Friendster vb. diğer sosyal ağları haftalık kullanma süresi anabilim dalına göre istatistiksel olarak anlamlı bir farkl111k göstermemektedir $\left(F_{11-1087}=0.980 ; p>0.05\right)$. 
Tablo 30. Öğretmen adaylarının haftalık podcasting kullanma süresinin sınıf, cinsiyet, kişisel bilgisayara sahip olma durumu ve internet bağlantısına sahip olma durumuna göre karşılaştırılması

\begin{tabular}{|c|c|c|c|c|c|c|c|}
\hline & & $\mathbf{f}$ & $\overline{\mathrm{x}}$ & Ss. & $\mathbf{t}$ & Sd. & $\mathbf{p}$ \\
\hline \multirow[t]{2}{*}{ Sinif } & 1 & 549 & 1.14 & .441 & \multirow{2}{*}{-.311} & \multirow{2}{*}{1092} & \multirow{2}{*}{.756} \\
\hline & 4 & 545 & 1.14 & .445 & & & \\
\hline \multirow[t]{2}{*}{ Cinsiyet } & Kadın & 745 & 1.12 & .413 & \multirow{2}{*}{-2.625} & \multirow{2}{*}{1092} & \multirow{2}{*}{$.009 *$} \\
\hline & Erkek & 349 & 1.19 & .498 & & & \\
\hline \multirow[t]{2}{*}{ PC Sahibi Olma } & Evet & 922 & 1.15 & .453 & \multirow{2}{*}{.978} & \multirow{2}{*}{1092} & \multirow{2}{*}{.328} \\
\hline & Hayır & 172 & 1.11 & .382 & & & \\
\hline \multirow{2}{*}{$\begin{array}{l}\text { İnternet Bağlantısına } \\
\text { Sahip Olma }\end{array}$} & Evet & 891 & 1.15 & .445 & \multirow{2}{*}{1.155} & \multirow{2}{*}{1092} & \multirow{2}{*}{.248} \\
\hline & Hayır & 203 & 1.11 & .432 & & & \\
\hline
\end{tabular}

Tablo 30, öğretmen adaylarının haftalık podcasting kullanma süresinin sınıf, cinsiyet, kişisel bilgisayara sahip olma durumu ve internet bağlantısına sahip olma durumuna göre karşılaştırılma sonuçlarını göstermektedir. Buna göre;

- 1. Sınıfta öğrenim gören adaylarının ortalamaları ( $\bar{x}=1.14$; Ss.=.441) ile 4. Sinıfta öğrenim gören adayların ortalamaları $(\overline{\mathrm{x}}=1.14 ; \mathrm{Ss} .=.445)$ arasında istatistiksel olarak anlamlı bir fark olmadı $\breve{~}_{1}$ tespit edilmiştir $\left(\mathrm{t}_{1092}=-0.311 ; \mathrm{p}>0.05\right)$.

- Kadın adaylarının ortalamaları ( $\overline{\mathrm{x}}=1.12$; Ss.=0.413) ile erkek adayların ortalamaları $(\overline{\mathrm{x}}=1.19 ;$ Ss. $=0.498)$ arasında erkek adayların lehine istatistiksel olarak anlamlı bir fark olduğu tespit edilmiştir $\left(\mathrm{t}_{1092}=--2.625 ; \mathrm{p}<0.05\right)$.

- Kişisel bilgisayara sahip olan adaylarının ortalamaları $(\bar{x}=1.19$; Ss. $=0.498)$ ile kişisel bilgisayara sahip olmayan adayların ortalamaları $(\overline{\mathrm{x}}=1.15$; Ss. $=0.453)$ arasında istatistiksel olarak anlamlı bir fark olmadığ tespit edilmiştir $\left(\mathrm{t}_{1092}=0.978 ; \mathrm{p}>0.05\right)$.

- İnternet bağlantısına sahip olan adaylarının ortalamaları $(\overline{\mathrm{x}}=1.15$; Ss. $=0.445)$ ile internet bağlantısına sahip olmayan adayların ortalamaları $(\overline{\mathrm{x}}=1.11$; Ss. $=0.432)$ arasında istatistiksel olarak anlamlı bir fark olmadığı tespit edilmiştir $\left(\mathrm{t}_{1092}=1.155 ; \mathrm{p}>0.05\right)$.

Tablo 31. Öğretmen adaylarının haftalık podcasting kullanma süresinin anabilim dalına göre karş1laştırılması

\begin{tabular}{lccccc}
\hline Varyansın Kaynağı & Kareler Toplamı & Sd. & Kareler Ortalaması & F & p \\
\hline Gruplar arası & 2.305 & 11 & .210 & & \\
Grup içi & 212.017 & 1082 & .196 & 1.069 & .383 \\
Toplam & 214.322 & 1093 & & & \\
\hline
\end{tabular}

Tablo 31 öğretmen adaylarının haftalık podcasting kullanma süresinin anabilim dalına göre karşılaştırılma sonuçlarını göstermektedir. Buna göre öğretmen adaylarının haftalık podcasting kullanma süresi anabilim dalına göre istatistiksel olarak anlamlı bir farklılık göstermemektedir $\left(\mathrm{F}_{11-}\right.$ $1082=1.069 ; \mathrm{p}>0.05)$. 
Tablo 32. Öğretmen adaylarının medya okuryazarlık düzeyleri

\begin{tabular}{lccc}
\hline Medya Okuryazarlı̆̆ Alt Boyutları & f & $\overline{\mathbf{x}}$ & Ss. \\
\hline Medya okuryazarlı̆̆ (GENEL) & 1101 & 3.43 & 0.45 \\
Ağ paylaşımı & 1101 & 3.32 & 0.83 \\
Görselleştirme & 1101 & 4.14 & 0.55 \\
Muhakeme & 1101 & 4.04 & 0.55 \\
Ortak akıl & 1101 & 3.80 & 0.59 \\
Oynama/ deneme & 1101 & 3.62 & 0.77 \\
Müzakere & 1101 & 3.56 & 0.81 \\
Simülasyon / benzetim & 1101 & 3.07 & 1.01 \\
Yapma / icra etme & 1101 & 2.63 & 0.94 \\
Uyarlama/kendine mal etme & 1101 & 2.82 & 0.90 \\
Çoklu görev & 1101 & 3.53 & 0.77 \\
Ortamlar arası konumlandırma & 1101 & 3.04 & 1.13 \\
Yayılmış/genişletilmiş biliş & 1101 & 3.62 & 0.70 \\
\hline
\end{tabular}

Tablo 32, öğretmen adaylarının medya okuryazarlık düzeylerini göstermektedir. Buna göre, öğretmen adaylarının medya okuryazarlık genel düzeyinde 3.43 ortalamaya sahip oldukları tespit edilmiştir. Öğretmen adaylarının en yüksek ortalamaya "görselleştirme" ve "muhakeme" alt boyutlarında sahip olduğu, en düşük ortalamaya ise "yapma/icra etme" ve "uyarlama/kendine mal" etme alt boyutlarında sahip olması dikkat çekmektedir. Verilerin toplandığ 1 ölçme aracının 1-5 puan arasında puanlandığı dikkate alındığında aday öğretmenlerin görselleştirme ve muhakeme alt boyutları dışında diğer alt boyutlarındaki düzeylerinin yeteri kadar yüksek olmadığı söylenebilir. Öğretmen adaylarının medya okuryazarlık düzeyinin gerek genelinde gerekse alt boyutlarında yetersiz oluşu ilgili konularda formal bir eğitim alınmamış olması ile ilişkilendirebilir.

Tablo 33. Medya okuryazarlık genel düzeyinin sınıf, cinsiyet, kişisel bilgisayara sahip olma durumu ve internet bağlantısına sahip olma durumuna göre karşılaştırılması

\begin{tabular}{llcccccc}
\hline & & $\mathbf{f}$ & $\overline{\mathbf{x}}$ & Ss. & $\mathbf{t}$ & Sd. & p \\
\hline Sinıf & 1 & 555 & 3.44 & 0.45 & \multirow{2}{*}{.599} & \multirow{2}{*}{1099} & .549 \\
Cinsiyet & 4 & 546 & 3.42 & 0.45 & & & \\
& Kadın & 751 & 3.39 & 0.44 & -3.873 & 1099 & $.000^{*}$ \\
PC Sahibi Olma & Erkek & 350 & 3.50 & 0.45 & & & \\
\multirow{2}{*}{ İnternet Bağlantısına Sahip Olma } & Evet & 927 & 3.44 & 0.44 & 2.726 & 1099 & $.007^{*}$ \\
& Hayır & 174 & 3.34 & 0.46 & & & \\
& Evet & 897 & 3.44 & 0.44 & 2.182 & 1099 & $.029^{*}$ \\
\hline
\end{tabular}

*: $\mathrm{p}<0.05$

Tablo 33, öğretmen adaylarının medya okuryazarlık düzeyinin sınıf, cinsiyet, kişisel bilgisayara sahip olma durumu ve internet bağlantısına sahip olma durumuna göre karşılaştırılma sonuçlarını göstermektedir. Buna göre;

- 1. Sınıfta öğrenim görmekte olan öğretmen adaylarının medya okuryazarlık düzeyi $(\bar{x}=3.44$; Ss.=0.45) ile 4. Sınıfta öğrenim gören öğretmen adaylarının düzeyi ( $\bar{x}=3.42$; Ss. $=0.45)$ arasında istatistiksel olarak anlamlı bir fark tespit edilmemiştir $\left(\mathrm{t}_{1099}=0.599 ; \mathrm{p}>0.05\right)$.

- Kadın öğretmen adaylarının medya okuryazarlık düzeyi $(\overline{\mathrm{x}}=3.39$; Ss. $=0.44)$ ile erkek öğretmen adaylarının medya okuryazarlık düzeyi ( $\overline{\mathrm{x}}=3.50$; Ss. $=0.45)$ arasında erkek öğretmen adaylarının lehine istatistiksel olarak anlamlı bir fark olduğu tespit edilmiştir $\left(\mathrm{t}_{1099}=3.873 ; \mathrm{p}<0.05\right)$. 
- Kişisel bilgisayara sahip olan öğretmen adaylarının medya okuryazarlık düzeyi $(\overline{\mathrm{x}}=3.44$; Ss. $=0.44$ ) ile kişisel bilgisayara sahip olmayan öğretmen adaylarının medya okuryazarlık düzeyi $(\overline{\mathrm{x}}=3.34$; Ss. $=0.46)$ arasında kişisel bilgisayara sahip olan öğretmen adaylarının lehine istatistiksel olarak anlamlı bir fark olduğu tespit edilmiştir $\left(\mathrm{t}_{1099}=2.726 ; \mathrm{p}<0.05\right)$.

- İnternet bağlantısına sahip olan öğretmen adaylarının medya okuryazarlık düzeyi $(\bar{x}=3.44$; Ss. $=0.44)$ ile internet bağlantısına sahip olmayan öğretmen adaylarının düzeyi $(\overline{\mathrm{x}}=3.37$; Ss.=0.46) arasında internet bağlantısına sahip olan öğretmen adaylarının lehine istatistiksel olarak anlamlı bir fark olduğu $\left(\mathrm{t}_{1099}=2.187 ; \mathrm{p}<0.05\right)$ tespit edilmiştir.

Tablo 34. Medya okuryazarlık genel düzeyinin öğrenim görülen anabilim dalına göre karşılaştırılması

\begin{tabular}{lcccccc}
\hline & Kareler Toplamı & Sd. & Kareler Ortalaması & F & p & Fark** \\
\hline Gruplar aras1 & 5.287 & 11 & .481 & & & \\
Grup içi & 214.372 & 1089 & .197 & 2.442 & $.005^{*}$ & $2-8,4-8$ \\
Toplam & 219.660 & 1100 & & & & \\
\hline
\end{tabular}

*: $\mathrm{p}<0.05$

**:1-Alman Dili Eğitimi, 2-BÖTE, 3-Coğrafya Eğitimi, 4-Fen Bilgisi Eğitimi, 5-İngiliz Dili Eğitimi, 6-Japon Dili Eğitimi,

7- Müzik Eğitimi, 8-Okul Öncesi Eğitimi, 9-Resim-İş Eğitimi, 10-Sınıf Öğretmenliği, 11-Tarih Eğitimi, 12-Türkçe Eğitimi

Tablo 34, öğretmen adaylarının medya okuryazarlık düzeyinin öğrenim gördükleri anabilim dalına göre karşılaştırılmasını göstermektedir. Buna göre öğretmen adaylarının medya okuryazarlık düzeyinin öğrenim gördükleri bölüm/anabilim dalına göre istatistiksel olarak anlamlı bir farklılık gösterdiği tespit edilmiştir $\left(\mathrm{F}_{11-1089}=2.442 ; \mathrm{p}<0.05\right)$. Farklılığın kaynağını belirlemek için yapılan Tukey testi ile yapılan ikili karşılaştırmalarda; Okul Öncesi Eğitimi anabilim dalında öğrenim gören öğretmen adaylarının medya okuryazarlık düzeyi $(\bar{x}=3.32$; Ss.=0.44) ile BÖTE bölümünde öğrenim gören öğretmen adaylarının düzeyi $(\overline{\mathrm{x}}=3.53$; Ss. $=0.47)$ arasında BÖTE öğretmen adaylarının lehine ve Fen Bilgisi Eğitimi anabilim dalında öğrenim gören öğretmen adaylarının düzeyi ( $\bar{x}=3.50$; Ss. $=0.43)$ ile Okul Öncesi Eğitimi anabilim dalında öğrenim gören öğretmen adaylarının düzeyi ( $\bar{x}=3.32$; Ss. $=0.44)$ arasında Fen Bilgisi Eğitimi öğretmeni adaylarının lehine istatistiksel olarak anlamlı bir fark olduğu tespit edilmiştir $(\mathrm{p}<0.05)$.

Öğretmen adaylarının sınıf düzeyi, cinsiyet, kişisel bilgisayara sahip olma, internet bağlantısına sahip olma ve öğrenim görülen anabilim dalı değişkenlerini kullanarak medya okuryazarlık düzeylerini tahmin etmek için kategorik olan değişkenler kukla değişkene dönüştürülerek, adımsal (stepwise) yöntemi ile çoklu doğrusal regresyon analizi uygulanmıştır. Analiz sürecinde sınıf (4. Sınıf olmak), internet bağlantısına sahip olmak, Alman Dili Eğitimi öğretmen adayı olmak, BÖTE öğretmen adayı olmak, Coğrafya Eğitimi öğretmen adayı olmak, Fen Bilgisi Eğitimi öğretmen adayı olmak, İngiliz Dili Eğitimi öğretmen adayı olmak, Japon Dili Eğitimi öğretmen adayı olmak, Müzik Eğitimi öğretmen adayı olmak, Okul Öncesi Eğitimi öğretmen adayı olmak, Resim-İş Eğitimi öğretmen adayı olmak, Sınıf Öğretmenliği öğretmen adayı olmak, Tarih Eğitimi öğretmen adayı olmak ve Türkçe Eğitimi öğretmen adayı olmak değişkenleri medya okuryazarlık düzeyinin istatistiksel olarak anlamlı yordayıcısı olmadıkları için kullanılan regresyon yöntemiyle (stepwise) analiz sonuçlarından çıkartılmıştır. Sonuç olarak; medya okuryazarlık düzeyini tahmin etmekte kullanılabilecek istatistiksel olarak anlamlı dört farklı model ortaya çıkmıştır. 
Tablo 35. Medya okuryazarlık düzeyinin tahmin edilmesi için regresyon modelleri

\begin{tabular}{|c|c|c|c|c|c|c|}
\hline Model & & Kareler Toplamı & Sd. & Kareler Ortalaması & $\mathbf{F}$ & p \\
\hline \multirow[t]{3}{*}{1} & Regresyon & 2.958 & 1 & 2.958 & 15.002 & $.000^{\mathrm{b}}$ \\
\hline & Kalan & 216.701 & 1099 & .197 & & \\
\hline & Toplam & 219.660 & 1100 & & & \\
\hline \multirow[t]{3}{*}{2} & Regresyon & 5.014 & 2 & 2.507 & 12.823 & $.000^{\mathrm{c}}$ \\
\hline & Kalan & 214.646 & 1098 & .195 & & \\
\hline & Toplam & 219.660 & 1100 & & & \\
\hline \multirow[t]{3}{*}{3} & Regresyon & 6.133 & 3 & 2.044 & 10.503 & $.000^{\mathrm{d}}$ \\
\hline & Kalan & 213.527 & 1097 & .195 & & \\
\hline & Toplam & 219.660 & 1100 & & & \\
\hline \multirow[t]{3}{*}{4} & Regresyon & 6.917 & 4 & 1.729 & 8.908 & $.000^{\mathrm{e}}$ \\
\hline & Kalan & 212.743 & 1096 & .194 & & \\
\hline & Toplam & 219.660 & 1100 & & & \\
\hline
\end{tabular}

a. Bağımlı Değişken: Medya Okuryazarlık Düzeyi

b. Yordayıc1: (Sabit), Erkekler

c. Yordayıc1: (Sabit), Erkekler, Kişisel bilgisayar sahibi

d. Yordayıc1: (Sabit), Erkekler, Kişisel bilgisayar sahibi, Okul Öncesi Eğitimi öğretmen adayı

e. Yordayıcı: (Sabit), Erkekler, Kişisel bilgisayar sahibi, Okul Öncesi Eğitimi öğretmen adayı, Fen Bilgisi Eğitimi öğretmen adayı

Tablo 25, öğretmen adaylarının medya okuryazarlık düzeyinin tahmin edilmesi için yapılan regresyon analizi sonuçlarını göstermektedir. Buna göre;

- Model 1'de yordayıcı değişken sadece cinsiyet (erkek) tir. Model 1, toplam varyansın \%0,1'ini $\left(\mathrm{R}^{2}=0.013\right)$ açıklamakta ve istatistiksel olarak anlamlı bir regresyon modelidir $\left(\mathrm{F}_{1-1099}=15.002\right.$; $\mathrm{p}<0.05)$.

- Model 2'de yordayıcı değişkenler cinsiyet (erkek) ve kişisel bilgisayar sahibi olmaktır. Model 2 , toplam varyansın $\% 0,2$ 'sini $\left(\mathrm{R}^{2}=0.023\right)$ açıklamakta ve istatistiksel olarak anlamlı bir regresyon modelidir $\left(\mathrm{F}_{2-1098}=12.823 ; \mathrm{p}<0.05\right)$.

- Model 3'te yordayıcı değişkenler cinsiyet (erkek), kişisel bilgisayar sahibi olmak ve Okul Öncesi Eğitimi öğretmen adayı olmaktır. Model 3, toplam varyansın \%0,3’ünü $\left(\mathrm{R}^{2}=0.028\right)$ açıklamakta ve istatistiksel olarak anlamlı bir regresyon modelidir $\left(F_{3-1097}=10.503 ; p<0.05\right)$.

- Model 4'te ise yordayıcı değişkenler cinsiyet (erkek), kişisel bilgisayar sahibi olmak, Okul Öncesi Eğitimi öğretmen adayı olmak ve Fen Bilgisi Eğitimi öğretmeni adayı olmaktır. Model 4, toplam varyansın \%0,3'ini $\left(\mathrm{R}^{2}=0.031\right)$ açıklamakta ve istatistiksel olarak anlamlı bir regresyon modelidir $\left(\mathrm{F}_{4-1096}=8.908 ; \mathrm{p}<0.05\right)$.

Tablo 36. Medya okuryazarlık düzeyini tahmin eden regresyon modelleri ve değişken katsayıları

\begin{tabular}{clccccc}
\hline Model & & B & SH & Beta & t & p \\
\hline 1 & (Sabit) & 3.393 & .016 & & 209.402 & .000 \\
& Cinsiyet (erkek) & .111 & .029 & .116 & 3.873 & .000 \\
2 & (Sabit) & 3.289 & .036 & & 91.555 & .000 \\
& Cinsiyet (erkek) & .123 & .029 & .128 & 4.255 & .000 \\
& Kişisel bilgisayar sahibi olmak & .119 & .037 & .097 & 3.243 & .001 \\
3 & (Sabit) & 3.309 & .037 & & 89.887 & .000 \\
& Cinsiyet (erkek) & .109 & .029 & .114 & 3.725 & .000 \\
& Kişisel bilgisayar sahibi olmak & .116 & .037 & .095 & 3.156 & .002 \\
& Okul Öncesi Eğitimi öğretmen adayı & -.094 & .039 & -.073 & -2.398 & .017 \\
4 & (Sabit) & 3.295 & .037 & & 87.983 & .000 \\
& Cinsiyet (erkek) & .115 & .029 & .119 & 3.897 & .000 \\
& Kişisel bilgisayar sahibi olmak & .117 & .037 & .095 & 3.182 & .002 \\
& Okul Öncesi Eğitimi öğretmen adayı & -.081 & .040 & -.063 & -2.039 & .042 \\
& Fen Bilgisi Eğitimi öğretmeni aday1 & .083 & .041 & .061 & 2.009 & .045 \\
\hline
\end{tabular}

Model 1 için $\mathrm{R}^{2}=0.013, \mathrm{p}<0.05$; Model 2 için $\mathrm{R}^{2}=0.023$, $\mathrm{p}<0.05$; Model 3 için $\mathrm{R}^{2}=0.028, \mathrm{p}<0.05$; Model 4 için $\mathrm{R}^{2}=0.031$, $\mathrm{p}<0.05$; 
Tablo 36, medya okuryazarlık düzeyini tahmin eden regresyon modelleri ve değişken katsayılarını göstermektedir. Buna göre;

Model 1'de regresyon modeli denklemi şu şekildedir:

MOKY $=3.393+[0.111 *$ cinsiyet $($ erkek $)]$.

Model 2'de regresyon modeli denklemi şu şekildedir:

MOKY $=3.289+[0.123 *$ cinsiyet $($ erkek $)]+[0.119 *$ kişisel bilgisayara sahip olma $]$.

Model 3 'te regresyon modeli denklemi şu şekildedir:

MOKY $=3.309+[0.109 *$ cinsiyet(erkek) $]+[0.109 *$ kişisel bilgisayara sahip olma $]-[0.094 *$ Okul Öncesi Eğitimi Öğrencisi olma].

Model 4'te regresyon modeli denklemi şu şekildedir:

MOKY $=3.295+[0.115 *$ cinsiyet $($ erkek $)]+[0.117 *$ kişisel bilgisayara sahip olma $]+[0.083 *$ Fen Bilgisi Eğitimi öğrencisi olma] - [0.081 * Okul Öncesi Eğitimi Öğrencisi olma].

\section{TARTIŞMA ve SONUÇ}

Araştırma sonuçları öğretmen adaylarının dijital medya araçlarını en çok boş zamanlarını değerlendirmek için kullandıklarını ve kullanım süresinin cinsiyete göre farklılık gösterdiğini göstermektedir. Kişisel bilgisayara ve internet bağlantısına sahip olanlar boş zamanlarını değerlendirmek için interneti daha uzun süre kullanmaktadır. Elde edilen bu sonuç alanyazın ile örtüşmektedir. İnternetin en çok boş zaman değerlendirmek için kullanıldığı ve erkek öğrencilerin kadın öğrencilere göre boş zamanlarını değerlendirmek için internet kaynaklarını daha fazla kullandığı (Tsai, 2004; Martin, 2009; Literat, 2011; Tutkun, Demir ve Genç, 2012) alanyazında da belirtilmektedir. Bununla birlikte, medyaya erişim olanaklarına sahip olma durumunun da medyayı kullanım sıklığını etkilediği gerek kuramsal çalışmalarda gerekse araştırma sonuçlarında ifade edilmektedir. (Silverblatt, 1995; Tsai, 2004; Buckingham, 2005; Jenkins, Clinton, Purushatma, Robison ve Weigel, 2007; UNESCO, 2008; Tornero ve Manuel, 2007; Almenara ve Liano, 2011; UNESCO, 2011).

Öğretmen adaylarının interneti okul ile ilgili işler için kullanma süresi öğrenim görülen sınıf düzeyine, internet bağlantısına sahip olma durumuna ve anabilim dalına göre farklılık göstermektedir. Alanyazında ilgili bir sonuca rastlanmamış olsa da bu durumun 4. Sınıfta öğrenim gören öğretmen adaylarının derslerinin genel olarak diğer sınıflara göre daha fazla araştırmaya ve uygulamaya dönük olmasından kaynaklandığı düşünülebilir. Ayrıca BÖTE bölümünde öğrenim gören adayların, branşları gereği okul ile ilgili işlerde internet kaynaklarına diğer anabilim dalları öğrencilerine göre daha fazla başvurması olağan karşılanabilir.

Öğretmen adayları sosyal ağlar içerisinde en çok Facebook ve Twitter'da zaman harcamaktadır. Benzer bir şekilde alanyazında da üniversite öğrencilerinin Facebook ve Twitter'da harcadıkları zamanın diğer sosyal ağlarda harcadıkları zamandan daha fazla olduğu belirtilmektedir (Joinson, 2008; Caverlee ve Webbs, 2008; Lenhart, 2009; Lewis, Kaufman ve Christakis, 2008; Martin, 2009; Literat, 2011; Tutkun, Demir ve Genç, 2012),

Araştırmada elde edilen kadın öğretmen adaylarının video izleme ve paylaşmaya yönelik sosyal ağlarda erkek öğrencilere göre daha fazla zaman harcadıkları bulgusu da Hartmann ve Klimmt (2006), Williams, Yee ve Caplan, (2008) ve Kim ve Kim'in (2009) çalışmaları ile tutarlıdır.

Erkek öğrencilerin hem tek kişilik hem de çevrimiçi oynanan video oyunlarında kız öğrencilere göre daha fazla zaman harcadıkları bulgusunun da (Quaiser-Pohl, Geiser ve Lehmann, 2006; Hartmann ve Klimmt, 2006; Williams, Yee ve Caplan, 2008; Kim ve Kim, 2009; Williams, Consalvo, Caplan ve Yee, 2009) alanyazında yapılan araştırmalarda belirtilen sonuçlarla tutarlı olduğu görülmektedir.

Araştırmada öğretmen adaylarının medya okuryazarlık düzeyine yönelik elde edilen bulgulardan; medya okuryazarlık düzeyinin cinsiyete, kişisel bilgisayar sahibi olma durumuna ve internet bağlantısına sahip olma durumuna göre farklılık gösterdiği bulgusu da alanyazında yapılan araştırmalar (Silverblatt, 1995; Tsai, 2004; Buckingham, 2005; Jenkins, Clinton, Purushatma, Robison ve Weigel, 2007; UNESCO, 2008; Tornero ve Manuel, 2007; Caverlee ve Webbs, 2008; Almenara ve Liano, 2011) ile benzerlik göstermektedir. 
$\mathrm{Bu}$ araştırmada elde edilen bulgularda birisi de medya okuryazarlık düzeyinin öğrenim görülen bölüme göre farkl1lık gösterdiğidir. Bu bulgu da alanyazın (Martin, 2009; Literat, 2011; Tutkun, Demir ve Genç, 2012; Lenhart, 2009; Joinson, 2008; Caverlee ve Webbs, 2008; Lewis, Kaufman ve Christakis, 2008; Martin, 2009; Lenhart, 2009) ile tutarlıdır. Ancak bu çalışmada farklılığın kaynağına yönelik yapılan incelemelerde araştırmada sadece Okul Öncesi Eğitimi-BÖTE ve Okul Öncesi Eğitimi-Fen Bilgisi Eğitimi öğrencileri arasında anlamlı fark tespit edilmiştir. Bu bulgu ise alanyazın tarafından tam olarak desteklenen bir bulgu değildir.

Araştırma sonuçları dört değişkenin (cinsiyet, kişisel bilgisayar sahibi olma, Okul Öncesi Eğitimi öğretmen adayı olma ve Fen Bilgisi Eğitimi öğretmen adayı olma) medya okuryazarlık düzeyini tahmin etmekte kullanılabileceğini göstermiş̧ir. Elde edilen bu sonuç medya okuryazarlık düzeyinin cinsiyete göre farklılık gösterdiğini belirten çalışmalarla (Silverblatt, 1995; Tsai, 2004; Buckingham, 2005; Jenkins, Clinton, Purushatma, Robison ve Weigel, 2007; UNESCO, 2008; Tornero ve Manuel, 2007; Caverlee ve Webbs, 2008; Almenara ve Liano, 2011) tutarlıdır.

Sonuç olarak, araştırma sonuçları öğretmen adaylarının dijital medya okuryazarlık düzeylerinin yeterli ve istenen düzeyde olmadığını göstermektedir. Hızla gelişen teknoloji ve buna bağlı olarak ortaya çıkan yeni medya ve katılım türleri bireylerin bu hususlarda yetkin hale getirilmesi için eğitim sistemlerinin güncellenmesi gerekliliğini de beraberinde getirmektedir. Eğitim sistemlerinin yanı sıra toplumun diğer unsur ve kurumlarının da bu değişime ayak uydurmada birey ve topluma yardımcı olması gerekmektedir. Birbiriyle ilişkili olan bu iki yeterliğin öğretmen yetiştirme programlarında ele alınması toplumsal bir ihtiyaç olarak karşımıza çıkmaktadır. Öğretmenler de genç kuşaklara yön verme özelliklerinden dolayı çağın gerektirdiği değişimlere hızla ayak uydurması gereken grupların başında gelmektedir. Bu bağlamda öğretmenler gerek hizmet öncesinde gerekse hizmet içinde çağdaş gelişmelere ayak uydurabilmeleri için desteklenmelidir (OFSTED, 2012). Medya okuryazarlığ becerileri alan yazında günümüz dünyasına ayak uydurabilmek için en önemli araçlardan, yeterliklerden birisi olarak ifade edilmektedir.

Alan yazın incelendiğinde birçok ülkenin öğretmenleri medya okuryazarlık becerileri hususunda yetiştirmenin önemini fark ettiği ve öğretmen yetiştirme programlarında ilgili becerilere yer vermeye başlandığı dikkat çekmektedir (Hobbs, 2010; Torres, 2006; UNESCO, 2011; Almenara ve Liano, 2011; Dezuanni, Kapitzke ve Iyer, 2010; UNESCO, 2008; Peterson ve Knowles, 2009; Jenkins ve diğerleri, 2007; Robertson ve Hughes, 2011). Ancak ülkemizde öğretmen adaylarının medya okuryazarlık becerilerinin geliştirilmesi ya da desteklenmesi yönündeki girişimler yeterli değildir. Aday öğretmenlerin bu konudaki yeterlikleri şansa ya da informal eğitime bırakılmaktadır.

Medya okuryazarlığı eğitiminde karşılaşılan başlıca sorunlar; yetersiz ders materyalleri, olumsuz öğretmen tutumları, gerekli teknik altyapı, okul yöneticilerin ilgisizliği ve öğretmenlerin bilgi ve beceri eksikliğidir (Tiiede ve Grafe, 2016; Tornero ve Manuel, 2007; Torres, 2006; Robertson ve Hughes, 2011; Hunneshagen, 2005; Andersen, Duncan ve Pungente, 1999; Lauri, Borg, Günnel ve Gillum, 2010). Bu sorunların giderilebilmesinde şüphesiz öğretmenlerin medya okuryazarlığı konusunda yetiştirilmeleri önemli bir yer tutmaktadır. Araştırma sonucunda öğretmen adaylarının medya okuryazarlık düzeylerinin yetersiz olduğunun ortaya çıtığı düşünüldüğünde medya okuryazarlığı dersini veren öğretmenlerin bu konuda ne kadar bilgi, beceri ya da olumlu tutum sahibi olduğu şüphe konusudur. Medya okuryazarlığı eğitiminde öğretmenlerin tutum ve niteliklerinden dolayı karşılaşılan güçlükleri yenmekte özellikle öğretmen yetiştirme programlarına büyük görevler düştüğünü ve programlarda medya okuryazarlığı konularına yer verilmesi gerekliliğinin toplumsal bir ihtiyaç olarak karşımıza çıktığı alanda yapılan araştırmalarda da vurgulanmaktadır. (Robertson ve Hughes, 2011; Andersen, Duncan ve Pungente, 1999; Hobbs, 2007; Hobbs, 2010).

$\mathrm{Bu}$ ihtiyaçtan hareketle UNESCO tarafından 2011 yılında hazırlanan "Öğretmenler için Medya ve Bilgi Okuryazarlığa Programının” içerisinde Türkçe'nin de bulunduğu farklı dillere çevrilerek yayınlanmıştır. Mevcut öğretmenlerin kullanabilmesi ve öğretmen yetiştirme programlarıyla bütünleştirilebilir olmasına özen gösterilerek hazırlanan program medya okuryazarlığı eğitimi hususunda radyo, televizyon, internet, gazete, kitap, dijital arşiv ve kütüphane gibi medya kaynaklarının medya okuryazarlığı eğitimi bünyesinde birleştirilmesine öncülük etmektedir (Wilson, Grizzle, Tuazon, Akyempong ve Cheung, 2011; Wilson, 2012; UNESCO, 2011). 
Alanyazın incelenerek ortaya çıkan öğretmen yetiştirme programlarında medya okuryazarlığı bilgi ve becerilerine yer verilmesi ihtiyacı ülkemiz için de geçerlidir. Zira öğretmen yetiştirme programlarımızda medya okuryazarlığı konularına 2018 yılına kadar yer verilmemiştir. Bu tarihten itibaren de uygulamaya koyulan öğretmen yetiştirme programlarında ise "Medya Okuryazarlı̆̆ı" dersi BÖTE bölümünde alan eğitimi bünyesinde zorunlu bir ders, diğer anabilim dalı programlarda ise seçmeli ders kategorisinde okutulmaya başlanmıştır. Bu bağlamda ülkemizde öğretmen adaylarının medya okuryazarlık düzeylerinin geliştirilmesi ya da desteklenmesi yönündeki girişimler yeterli değildir. Aday öğretmenlerin bu konudaki yeterliklerini geliştirmesi şansa bırakılmamalı, öğretmen yetiştirme programlarında daha etkili bir şekilde ele alınmalıdır.

Her çalışma gibi bu çalışmanın kendi sınırlamaları vardır. Birincisi, bu çalışma sadece nicel verilere dayanmaktadır. Bu bağlamda öğretmen adaylarının medya okuryazarlık düzeyleri nitel yöntemlerle derinlemesine analiz edilebilir. İkincisi ise, çalışmada veri toplama için tek eğitim fakültesinden oluşan bir örneklemenin kullanılmasıdır. Bu bağlamda daha geniş ve büyük örneklemler ya da evrenin tamamına ulaşılarak elde edilecek sonuçlar gerçeğe daha yakın sonuçlar ortaya çıkaracaktır. Genel olarak, bu çalışma öğretmen adaylarının dijital medya kullanım şekilleri ve süreleri, medya okuryazarlık düzeyleri ve medya okuryazarlık düzeyinin tahmin edilmesi konusundaki bilgilerimizi genişletmektedir.

\section{KAYNAKÇA}

Almenara, J. C., \& Liaño, S. G. (2011). La alfabetización y formación en medios decomunicación en la formación inicial del profesorado. Educacion XX1, 14(1), 89-115. https://doi.org/10.5944/educxx1.14.1.264

Andersen, N., Duncan, B., \& Pungente, J. (1999). Media Education in Canada - The Second Spring. C. Feilitzen, \& U. Carlsson (Ed.), Children and Media. Image, Education, Participation içinde (s. 139-162). Gothenburg: Nordicom

Aufderheide, P. (1993). Media Literacy: A Report of the National Leadership Conference on Media Literacy. Queenstown, Maryland: The Aspen Institute Wye Center.

Balcı, A. (2004). Sosyal Bilimlerde Araştırma Yöntem, Teknik ve Illkeler. Ankara: Pegema Yayıncıllk.

Baykul, Y. (1999). İstatistik Metodlar ve Uygulamalar. Ankara: Anı Yayıncılık.

Buckingham, D. (2003). Media Education: Literacy, Learning and Contemporary Culture. Cambridge: Polity Press.

Buckingham, D. (2005). The Media Literacy of Children and Young People: A Review of the Research Literature. London: OFCOM.

Buckingham, D. (2009). Media Education. Cambridge: Polity Press.

Caverlee, J., \& Webb, S. (2008). A Large-Scale Study of MySpace: Observations and Implications for Online Social Networks. E. Adar, M. Hurst, T. Finin, N. S. Glance, N. Nicolov, \& B. L. Tseng (Ed.), Proceedings of the Second International Conference on Weblogs and Social Media, \{ICWSM\} 2008, Seattle, Washington, USA, March 30 - April 2, 2008.

Dezuanni, M., Kapitzke, C., \& Iyer, R. (2010). Copyright, digital media literacies and preservice teacher education keywords. Digital Culture \& Education, 2(October), 230-245.

Duncan, B. (1989). Media literacy at the crossroads: Some issues, probes and questions. The History and Social Science Teacher, 24(4), 205-209.

European Commission. (2011). Testing and Refining Criteria to Assess Media Literacy Levels in Europe. Brussels: European Commission.

Federov, A. (2008). A media education around the world: Brief history. Acta Didactica Napocensia, 1(2), s. 5668.

Field, A. (2005). Discovering Statistics Using SPSS. London: SAGE.

Hartmann, T. and Klimmt, C. (2006). Gender and computer games: exploring females' dislikes. Journal of Computer-Mediated Communication, 11: 910-931. doi:10.1111/j.1083-6101.2006.00301.x

Hobbs, R. (1998). Building citizenship skills through media literacy education. M. Salvador ve P. Sias (ed.), The Public Voice in a Democracy at Risk içinde (s. 57-76). Westport: Praeger Press.

Hobbs, R. (2007). Approaches to Instruction and Teacher Education in Media Literacy. Doha: UNESCO.

Hobbs, R. (2010). Digital and Media Literacy: A Plan of Action. Washington: The Aspen Institute. 
Hobbs, R., ve Jensen, A. (2009). The past, present and the future of media literacy education. Journal of Media Literacy Education, 1(1), 1-11.

Hunneshagen, H. (2005). Innovationen in Schulen. Lowther: Waxman Inan.

Jenkins, H., Purushhotma, R., Weigel, M., Clinton, K., ve Robison, A. J. (2006). Confronting the Challenges of Participatory Culture: Media Education in 21st Century. London: The MIT Press.

Jenkins, H., Clinton, K., Purushatma, R., Robison, R., ve Weigel, M. (2007). Confronting the Challenges of a Participatory Culture: Media Education for the 21st Century. Nordic Journal of Media Literacy, 1(02), 98113.

Joinson, A.N. (2008) Looking at, Looking up or Keeping up with People? Motives and Use of Facebook. Proceedings of the SIGCHI Conference on Human Factors in Computing Systems içinde, ACM, New York, 1027-1036. https://doi.org/10.1145/1753326.1753613

Karasar, N. (2005). Bilimsel Araştırma Yöntemi. Ankara: Nobel Yayın Dağıtım.

Kim, H., ve Kim, J. (2009). IASDR 2009. A Study on Gender Difference in the Use of Digital Games: Focused on Self-Realization of Game Players, 4047-4050. Seul.

Kubey, R. (2001). Media Literacy in the Information Age, Current Perspectives. New Jersey: Transaction Publishers.

Lauri, M. A., Borg, J., Günnel, T., ve Gillum, R. (2010). Attitudes of a sample of English, Maltese and German teachers towards media education. European Journal of Teacher Education, 33(1), 79-98.

Literat, I. (2011). Teachers College Educational Technology Conference (TCETC) Proceedings. Measuring New Media Literacies; Towards the Development of a Comprehensive Assessment Tool, 15-27. New York

Lenhart, A. (2009). Adults and Social Network Websites. Pew Internet \& American Life Project.

Lewis, K., Kaufman, J., ve Christakis, N. (2008). The taste for privacy: An analysis of college student privacy settings in an online social network. Journal of Computer-Mediated Communication, 14(2008), 79-100.

Livingstone, S., Wang, Y. (2011). Media literacy and the Communications Act: what has been achieved and what should be done? LSE Media Policy Project Series, Micova, B., Sujon, S., Zoetanya and Tambini, Damian, Z. Ve Danizan Z.(Ed.) (Media Policy Brief 2). Department of Media and Communications, London School of Economics and Political Science, London, UK.

Martin, C. (2009). Social Networking Usage and Grades Among College Students: A Study to Determine the Correlation of Social Media Usage and Grades. Hampshire: University of New Hampshire-Whittemore School of Business \& Economics.

Masterman, L. (2001). Teaching the Media. Madison. Routledge.

Miles, M, B., \& Huberman, A. M. (1994). Qualitative Data Analysis: An Expanded Sourcebook. Thousand Oaks, CA: Sage.

Namita, Y. (2010). Teachers' Perceptions of Media Education in BC Secondary Schools: Challenges and Possibilities. Vancouver: The University of British Columbia.

OFSTED. (2012). Initial Teacher Education (ITE) Inspection Handbook. Manchester: Crown.

Peterson, A., ve Knowles, C. (2009). Active citizenship: a preliminary study into student teacher understandings. Educational Research, 51(1), 35-59.

Potter, W. J. (2005). Media Literacy. London: Sage Publications.

Quaiser-Pohl, C., Geiser, C., ve Lehmann, W. (2006). The relationship between computer-game preference, gender and mental-rotation ability. Personality and Individual Differences, 40(3), 609-619.

Radyo Televizyon Üst Kurulu. (2008). Medya Okuryazarlı̆̆ı Nedir? Ocak 25, 2012 tarihinde Medya Okuryazarlı̆̆1: https://www.medyaokuryazarligi.gov.tr/index.php adresinden alındı.

Richardson, E. (2009). A Theoretical Investigation into the Two Major Approaches to Media Literacy: A Proposal for a Hybrid. (Yayımlanmamış yüksek lisans tezi). Northeastern University.

Robertson, L., ve Hughes, J. M. (2011). Investigating pre-service teachers' understandings of critical media literacy. Language and Literacy, 13(2), 37-53.

Scharrer, E. (2003). Making a case for media literacy in the curriculum: Outcomes and assessment. Journal of Adolescent and Adult Literacy, 46(4), 354-358.

Schwarz, G. (2005). Overview: What Is Media Literacy, Who Cares and Why? Schwarz, G ve Brown P., Media Literacy: Transforming Curriculum and Teaching içinde (s. 5-17). Madlen: Blackwell Publishing. 
Silva, K., ve Wyatt, W. (2007). Reviving a Culture - Debating Public Through Media Education. Abel, S., Nowak, A. ve Ross, K. Rethinking Media Education: Critical Pedagogy and Identity Politics içinde (s. 1-16). Cresskill: Hampton Press.

Silverblatt, A. (1995). Media Literacy: Keys to Interpreting Media Messages. Westport: Praeger.

Thoman, E. (1999). Skills and strategies for media education. Educational Leadership, 56(5), 50-54.

Thoman, E., ve Jolls, T. (2003). Literacy for the 21st Century: An Overview \& Orientation Guide to Media Literacy Education. Santa Monica: Center for Media Literacy.

Thoman, E., ve Jolls, T. (2004). Media literacy-A national priority for a changing world. The American Behavioral Scientist, 48(1), 18-29.

Tiiede, J. \& Grafe, S. (2016). Media Pedagogy in German and U.S. Teacher Education. [Pedagogía mediática en la formación de profesores de Alemania y EEUU]. Comunicar, 49, 19-28. https://doi.org/10.3916/C492016-02

Tornero, P., \& Manuel, J. (2007). Study of the Current Trends and Approaches on Media Literacy in Europe. European Commission.

Torres, M. (2006). The need for critical media literacy in teacher education core curricula. Educational Studies, 39(3), 260-282.

Tsai, M. J. (2004). Gender Differences in Online Behaviors, Motivation and Attitudes. Cantoni, ve C. McLoughlin, Proceedings of World Conference on Educational Multimedia, Hypermedia and Telecommunications içinde (ss. 4409-4415). Chesapeake, VA: AACE.

Tutkun, T., Demir, M. K., Genç, S. Z. (2012). 21. Ulusal Eğitim Bilimleri Bildiri Özetleri. Öğretmen Adaylarının Medya Okuryazarlık Düzeyleri. İstanbul: Marmara Üniversitesi.

Tutkun, T. (2013). Öğretmen Adaylarının Medya Okuryazarlık Düzeyi İle Aktif Vatandaşlık Bileşenlerinden Temsili Demokrasiye, Protesto Ve Sosyal Değişime Katılım Düzeyi Arasındaki İlişki. (Yayımlanmamış doktora tezi). Çanakkale Onsekiz Mart Üniversitesi, Eğitim Bilimleri Enstitüsü.

UNESCO. (1982). Grunwald Declaratin on Media Education. Grunwald: UNESCO.

UNESCO. (2008). International Expert Group Meeting: Teacher Training Curricula Enrichment for Media and Information Literacy. Paris: UNESCO.

UNESCO. (2011). Community Media: A Good Practice Handbook. Paris: United Nations Educational, Scientific and Cultural Organization.

Williams, D., Consalvo, M., Caplan, S., ve Yee, N. (2009). Looking for gender: gender roles and behaviors among online gamers. Journal of Communication, 59(4)700-725.

Williams, D., Yee, N., ve Caplan, S. E. (2008). Who plays, how much, and why? Debunking the stereotypical gamer profile. Journal of Computer-Mediated, 13(4), 993-1018.

Wilson, C. (2012). Media and information literacy pedagogy and possibilities. Communicar, XX(39), 15-22.

Wilson, C., Grizzle, A., Tuazon, R., Akyempong, K., ve Cheung, C.-K. (2011). Media and Information Literacy Curriculum for Teachers. France: UNESCO. 